\title{
Las Cabras volcano, Michoacán-Guanajuato Volcanic Field, México: Topographic, climatic, and shallow magmatic controls on scoria cone eruptions
}

\author{
Marie-Noëlle Guilbaud ${ }^{1, *}$, Athziri Hernández-Jiménez ${ }^{2}$, \\ Claus Siebe ${ }^{1}$, and Sergio Salinas ${ }^{3}$
}

\author{
${ }^{1}$ Departamento de Vulcanología, Instituto de Geofísica, Universidad Nacional Autónoma de México, \\ Ciudad Universitaria, C.P. 04510 Coyoacán, Mexico City, Mexico. \\ ${ }^{2}$ Facultad de Ciencias, Universidad Nacional Autónoma de México, Ciudad Universitaria, \\ C.P. 04510 Coyoacán, Mexico City, Mexico. \\ ${ }^{3}$ Facultad de Ingeniería, División de Ingeniería en Ciencias de la Tierra, Universidad Nacional Autónoma de México, \\ Ciudad Universitaria, C.P. 04510 Coyoacán, Mexico City, Mexico. \\ *marie@igeofisica.unam.mx
}

\begin{abstract}
Scoria cones are abundant in most volcanic fields on Earth, such as the Michoacán-Guanajuato Volcanic Field, in the central-western sector of the Trans-Mexican Volcanic Belt. However, there are few indepth studies on their eruptive style and controlling factors, despite of their diversity in shape and composition which implies a wide range of hazards. Here, we present results of morphologic, stratigraphic, sedimentary, petrographic, and geochemical studies of the prominent Las Cabras scoria cone located west of the Zacapu lacustrine basin in the center of the Michoacán-Guanajuato Volcanic Field. This basaltic andesitic to andesitic volcano formed between 27 and 26 kyrs BP on the steep slopes $\left(>10^{\circ}\right)$ of the lava shield of El Tule volcano. Over time, its dominant eruptive style changed from Strombolian to effusive. Initial explosive activity built a 170-m-high scoria cone and deposited thick tephra fallout on the surrounding sloping terrain. Structures in the deposits indicate that early friable fine-grained tephra underwent significant erosion due to syn-eruptive heavy rain coupled with the sloping nature of the underlying ground. This erosion generated lahars that very likely reached the Zacapu lake based on the pre-eruptive topography. As the explosivity dropped, lava was emitted from the base of the cone first to the $\mathrm{S}$ and $\mathrm{SE}$, forming a thick, viscous lobe that filled a pre-existing E-W valley. The flow direction then deviated to the $\mathrm{N}$ and $\mathrm{NE}$, to form thinner, less-viscous lobes fed from the vent by an openchannel. The lavas are covered by hummocks made of agglutinates and bombs that indicate that the eruption terminated by catastrophic collapse of the SE sector of the cone, possibly triggered by the intrusion of magma within the cone, which destabilized its downslope segment. The sudden flank failure was potentially associated with a late effusive event and the hummocks may have been carried away by the lava surge. Whole-rock chemical variations and crystal disequilibrium textures point toward a complex magma feeding system, involving mixing and mingling between different magma batches. This study shows that the formation of scoria cones on a terrain with a marked slope $\left(>10^{\circ}\right)$ has profound impacts on the eruption dynamics and related hazards due to its effect on cone stability and ash erosion. It also evidences the erosive effect of syn-eruptive rain on fine-grained tephra, especially when deposited on a slope. Finally, it reveals the complex magmatic
\end{abstract}

processes that may occur in the shallow plumbing system of monogenetic andesitic volcanoes, which could be particularly important in inland areas of continental arcs.

Key words: Monogenetic; scoria cones; slope; tephra; erosion; magma mixing; Mexico.

\section{RESUMEN}

Los conos de escoria abundan en la mayoría de los campos volcánicos de la Tierra y en particular en el campo volcánico MichoacánGuanajuato, ubicado en el sector centro-occidental del Cinturón Volcánico Trans-Mexicano. Sin embargo, existen pocos estudios detallados de sus estilos eruptivos y los factores que los controlan, a pesar de su diversidad en formas y composiciones. En este documento presentamos el resultado de estudios morfológicos, cartográficos, estratigráficos, sedimentológicos, petrográficos y geoquímicos del cono de escoria Las Cabras localizado al oeste de la cuenca lacustre de Zacapu en el centro del campo volcánico Michoacán-Guanajuato. La erupción de este volcán basalto-andesítico $a$ andesítico tuvo lugar durante un periodo breve entre 27 y 26 mil años AP en la base inclinada del escudo de lavas del volcán El Tule. Con el tiempo, su estilo eruptivo cambió de Estromboliano a efusivo. La actividad explosiva temprana construyó un cono de escoria de $170 \mathrm{~m}$ de altura y depositó tefra de caída en las pendientes del terreno circundante. Las estructuras sedimentarias de los depósitos indican que la tefra temprana sufrió una erosión significativa debido a lluvias intensas y a su granulometría fina, así como a la pendiente del terreno. Cuando el nivel de explosividad disminuyó, la lava fue emitida desde la base del cono, primero hacia el sur y sureste, formando un espeso lóbulo de lava viscosa que rellenó un valle pre-existente, mismo que desembocaba hacia el lago de Zacapu. La dirección principal del flujo de lava cambió después hacia el norte y noreste, para formar lóbulos menos viscosos alimentados desde la ventila por medio de un canal abierto. Las lavas están cubiertas de montículos constituidos por aglutinados y bombas que indican que la erupción terminó con un colapso catastrófico de una cuarta parte del cono hacia el este, posiblemente disparado por la intrusión de lava dentro del cono, que desestabilizó su segmento orientado cuesta abajo. La falla

Guilbaud, M.-N., Hernández-Jiménez, A., Siebe, C., Salinas, S., 2021, Las Cabras volcano, Michoacán-Guanajuato Volcanic Field, México: Topographic, climatic, and shallow magmatic controls on scoria cone eruptions: Revista Mexicana de Ciencias Geológicas, v. 38, núm. 2, p. 101-121. 
súbita del flanco estuvo posiblemente asociada a un evento efusivo tardío $y$ los montículos pueden haber sido transportados por el surgimiento de la lava. A su vez, el amplio rango composicional de los productos y las texturas de desequilibrio de los cristales demuestran que ocurrieron procesos complejos en el conducto magmático, involucrando una mezcla parcial o total entre diferentes lotes de magma. En conclusión, este estudio demuestra que la formación de conos de escoria sobre una pendiente pronunciada $\left(>10^{\circ}\right)$ influye fuertemente en la dinámica eruptiva y los peligros asociados. También, evidencia el efecto erosivo de la lluvia sobre ceniza fina recién depositada en una pendiente. Finalmente, revela los procesos complejos que ocurren en el sistema magmático somero de los volcanes monogenéticos andesíticos, en particular en un contexto tectónico de arco continental.

Palabras clave: Volcanismo monogenético; estilo eruptivo; campo volcánico Michoacán-Guanajuato; tefra, erosión; mezcla de magmas; México.

\section{INTRODUCTION}

Until about twenty years ago, research in volcanology had traditionally focused on large active polygenetic volcanoes and highmagnitude eruptions, while small monogenetic volcanoes such as scoria cones were relatively neglected. This is mostly because of their small size and simple morphology that suggested both short-lived, simple magmatic systems with hence low scientific interest ("boring"), and low-magnitude eruptions with limited impacts and hence low concern for hazard assessments. However, there is increasing evidence that scoria cones can feed strong explosive activity, with far-distance impacts (Martin and Németh, 2006; Mannen and Ito, 2007; Pioli et al., 2008; Di Traglia et al., 2009; Lorenzo-Merino et al., 2018). Moreover, even local and regional-scale hazards cannot be neglected in a highly populated world, and detailed studies of scoria cones are crucial to estimate volcanic hazards in urban areas across the globe (e.g., Siebe and Macías, 2006; Houghton et al., 2006; Ort et al., 2008; Murcia et al., 2015; Hopkins et al., 2020). These small volcanoes also hold clues about fundamental processes such as the origin and evolution during transport of mantle-derived magmas, as they undergo limited differentiation and crustal contamination (e.g., Agustín-Flores et al., 2011; Rasoazanamparany et al., 2016; Jankovics et al., 2019; Larrea et al., 2017; 2019a; 2021; Albert et al., 2020; Ramírez-Uribe et al., 2021). In addition, they conserve information on shallow-level magma degassing and crystallization (Taddeucci et al., 2004; Pioli et al., 2009; Johnson et al., 2008; Riggs and Duffield, 2008), and their activity is strongly linked and hence indicative of structural controls on magma ascent (Settle, 1979; Takada, 1994; Tibaldi, 1995; Connor, 1990; Valentine and Keating, 2007; Valentine and Gregg, 2008; Osorio-Ocampo et al., 2018; Gómez-Vasconcelos et al., 2021). What has received comparatively less attention is their strong interaction with climatic conditions (such as torrential rain; Segerstrom 1950), the pre-eruptive and syn-eruptive topography (Németh et al., 2011; Kereszturi et al. 2012; Becerril et al., 2021), and the upper-crust composition (including the occurrence of magma bodies, such as sills or dikes), which will be illustrated here using the case of Las Cabras volcano in Michoacán, Mexico (Figure 1).

The Trans-Mexican Volcanic Belt (TMVB) is a $\sim 1000 \mathrm{~km}$ long active continental arc related to the subduction of the Rivera and Cocos Plates below North America (Figure 1). Scoria cones and other monogenetic vents are abundant along the TMVB and form large fields, the largest of these being the Michoacán-Guanajuato Volcanic Field, hereafter referred to as MGVF (Figure 1; Hasenaka and Carmichael, 1985; Connor, 1990). The MGVF includes >1100 small-to-medium sized Quaternary volcanic edifices, at least 20 of which formed in the Holocene (Hasenaka and Carmichael, 1985; Guilbaud et al., 2009; 2011; 2012; Chevrel et al., 2016; Mahgoub et al., 2017; Osorio-Ocampo et al., 2018; Reyes-Guzmán et al., 2018; 2021; Ramírez-Uribe et al., 2019; Larrea et al., 2019b; Macías and Arce, 2019). These studies report that volcanoes in the MGVF are dominantly scoria cones with lava flows and medium-sized shields, with some viscous flows without cones at source, domes, and rare maars. Seismic swarms were recorded in the field in February-March 1997 (Pacheco et al., 1999), May-July 2006 (Gardine et al., 2011), and January-February 2020 (SSN, 2020), probably recording episodes of dike injection and stalling in the crust (e.g., Albert et al., 2016). Hence, a new eruption is likely to happen in the coming decades in the MGVF, further stressing the need for a deep understanding of volcanic activity in this area (Guilbaud et al., 2012).

Historical documents and detailed petrographical and geochemical studies of the historic Jorullo (1759-1774) and Paricutin (1943-1952) volcanoes located in the south part of the MGVF (Figure 1) have provided a wealth of information about the dynamics of scoria cone eruptions (e.g., Ordóñez, 1947; Luhr and Simkin, 1993; Guilbaud et al., 2009; Pioli et al., 2008; 2009; Rowland et al., 2009; Johnson et al., 2010; Rasoazanamparany et al., 2016; Larrea et al., 2017; 2019a; 2021). Both started with strong explosive, violent-Strombolian phases, driven by high magma discharge rates and high magma viscosity (Pioli et al., 2008; Rowland et al., 2009). Later-on, explosive and effusive activity occurred simultaneously at both volcanoes (Luhr and Simkin, 1993), possibly due to magma-gas decoupling in a complex plumbing system underneath the cones (Krauskopf, 1948; Pioli et al., 2009). The magma emitted at the vent became more differentiated with time during these two eruptions, which was ascribed initially to assimilation and fractional crystallization in a magma chamber (Luhr and Carmichael, 1985; McBirney et al., 1987). Yet, more recent isotopic data suggest instead the involvement of distinct magma batches and hence a deeprooted branching magmatic system that would extend well below the edifice (Rowe et al., 2011; Rasoazanamparany et al., 2016; Larrea et al., 2019a). The Jorullo and Paricutin eruptions were however somewhat anomalous due to their large volumes $\left(>1 \mathrm{~km}^{3}\right)$ and it is unclear if these processes also occur during the eruption of smaller scoria cones. Furthermore, these two eruptions occurred at the southern margin of the volcanic field, and their eruptive processes may depend on their setting and hence not apply to other sectors. Therefore, detailed studies of smaller and hence more common scoria cones that are in inland sectors of the field are needed to obtain a more comprehensive understanding of the eruptive style and their controlling factors.

Here, we present results from the detailed study of Las Cabras volcano, a breached scoria cone with several lava lobes located in the central part of the MGVF (Figure 1) near the margin of a fault-bounded lake basin, and close to a cluster of Holocene vents (Siebe et al., 2014; Reyes-Guzmán et al., 2018). This volcano is morphologically similar to many other young scoria cones in the MGVF, yet its products display peculiar sedimentary and textural features that motivated this study. Using field, petrography and geochemical (major and trace element) data, we show that products from this small volcano document diverse processes such as magmatic and topographic controls on cone collapse, shallow-seated magma mingling, and syn-eruptive tephra erosion.

\section{TECTONIC AND VOLCANIC SETTING}

The MGVF occupies a whole segment of the TMVB, spreading across the entire arc width, which contrasts to other sectors of the belt where young monogenetic fields are more localized (Figure 1), and makes it of particular interest to investigate variations in monogenetic 


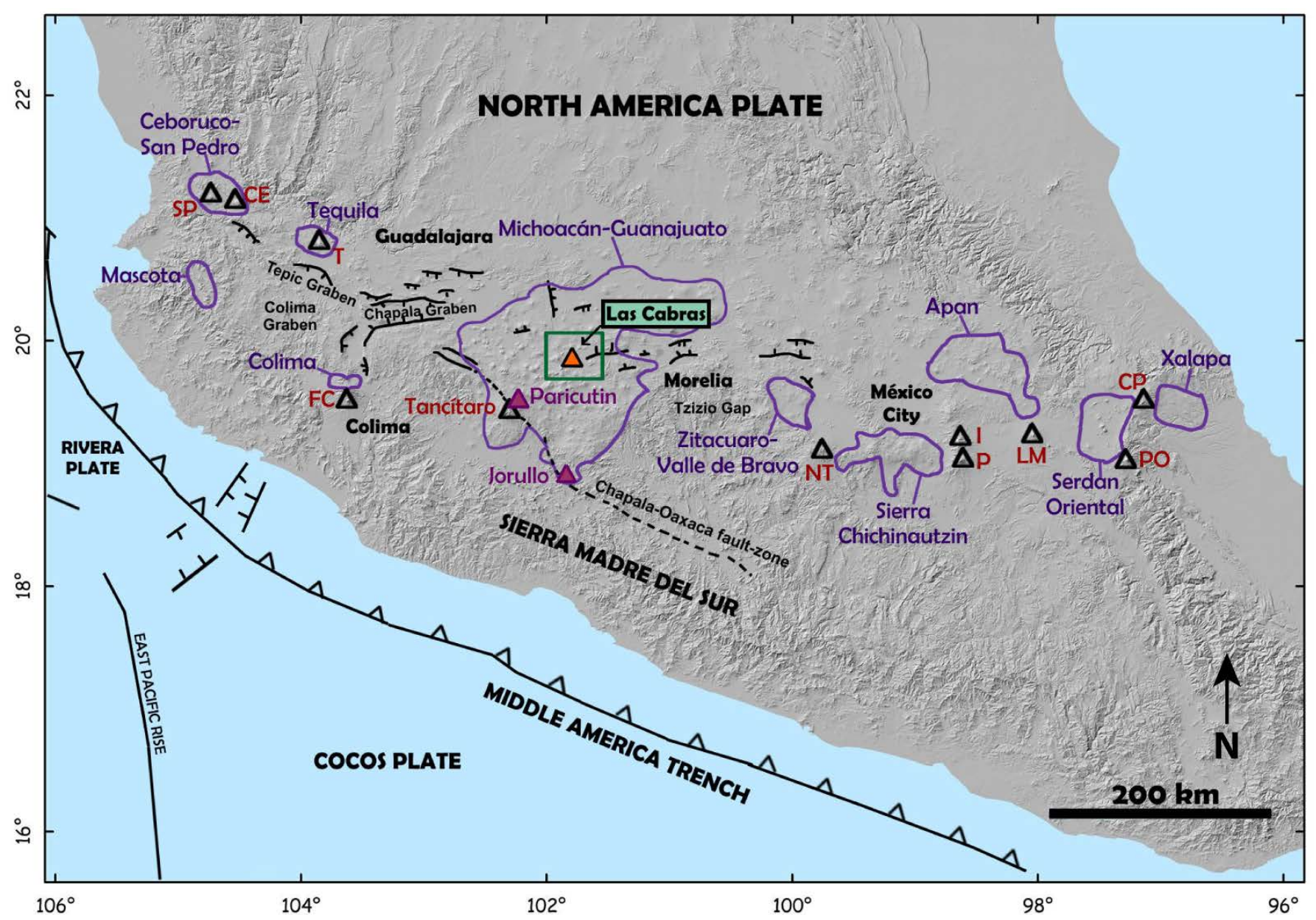

Figure 1. Location of Las Cabras volcano (orange triangle) in the Michoacán-Guanajuato Volcanic Field and the Trans-Mexican Volcanic Belt. The green square locates the map in Figure 2. The location of historic Jorullo and Paricutin volcanoes is indicated (purple triangles and line, respectively). Empty triangles mark the main stratovolcanoes (from west to east: SP: San Pedro, CE: Ceboruco, T: Tequila, FC: Fuego de Colima, NT: Nevado de Toluca, I: Iztaccíhuatl, P: Popocatépetl, LM: La Malinche, PO: Pico de Orizaba, CP: Cofre de Perote), and the major faults are also shown.

activity with space and hence tectonic setting. It has been proposed that the peculiarities of the MGVF reflect a low-angle slab subduction, that allows the conditions of mantle melting to be met over a wide area (Guilbaud et al., 2019). Magmas range from basaltic to rhyolitic in the MGVF, but most are andesitic (Hasenaka and Carmichael, 1987; Guilbaud et al., 2019). The majority of them have calc-alkaline signatures although alkaline OIB-types exist and occur throughout the field, probably reflecting peculiar characteristics of the mantle source (Blatter and Hammersley, 2010; Losantos et al., 2017; Guilbaud et al., 2019).

Las Cabras volcano is located in the central part of the MGVF, a region marked by large (5-10 km wide, $10-50 \mathrm{~km}$ long) highland depressions bordered by prominent normal faults. This zone is tectonically active as many of those faults displace Quaternary products, and some are linked with high-magnitude $(M>5)$ historical seismic events (Figure 1, see also Suter et al., 1992; 2001; Gómez-Vasconcelos et al., 2021). Such shallow extensional activity is probably caused by gravitational collapse of the belt, with some possible influence of slab rollback (Suter et al., 2001). The tectonic depressions or basins host or have hosted shallow lakes, many of them were drained in previous centuries for agricultural or urbanization purposes, including Zacapu lake (Noriega and Noriega, 1923).

More precisely, Las Cabras is located $10 \mathrm{~km}$ west of the plain of the Zacapu basin, an elongated $25 \mathrm{~km}$-long and $10 \mathrm{~km}$-wide depression filled with lacustrine sediments and intercalated tephra layers (Figure 2). Detailed mapping and radiometric dating conducted during the past 15 years allow to draw a clear picture of the volcanism in this area of the MGVF (Figure 2). So far, this data has been published for various sectors around the basin: the SE sector around the Alberca de Guadalupe maar (Kshirsagar et al., 2015), the NW sector around El Caracol tuff cone (Kshirsagar et al., 2016), the S sector around the Mazcuta cone near the town of Comanja (Ramírez-Uribe et al., 2019), and the W sector near Zacapu city (Reyes-Guzmán et al., 2018; 2021; Mahgoub et al., 2018) (Figure 2). These studies show that the basin has hosted intense and diverse volcanic activity since the Pliocene. The oldest volcanoes are the intensely eroded and strongly faulted shields that crop out mainly to the NE of the basin, dated at one site at $4.4 \pm 0.17$ $\mathrm{Ma}$ (Kshirsagar et al., 2015). These are followed in age by less-intensely faulted eroded lava shields, ignimbrite deposits, and lava flows dated at the early-Pleistocene period (1-2 Ma), and Mid-Pleistocene volcanoes (100 ka-1 Ma) with better preserved morphologies and no significant faults (Ban et al., 1992; Kshirsagar et al., 2015; Reyes-Guzmán et al., 2018). Finally, all of the above features are partially covered by young Late-Pleistocene to Holocene volcanoes with pristine morphology that occur all around the basin, but more particularly to its SW, forming a broad WSW-ENE alignment of vents west of Zacapu city (Figure 2). This latter area is of particular interest for assessing volcanic 

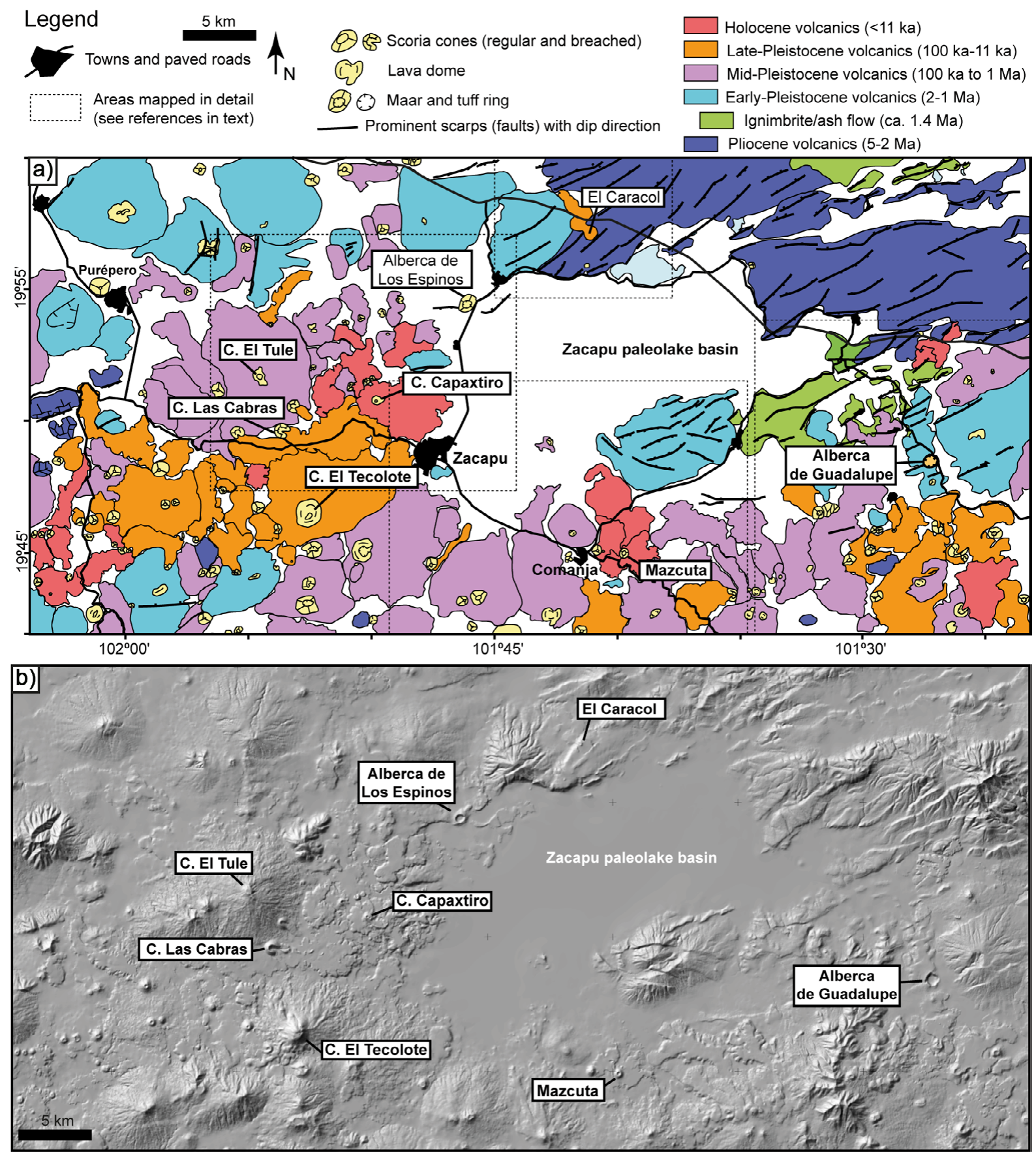

Figure 2. Geology of the Zacapu basin. a) Geological map constructed with the aid of a 5-m-resolution digital elevation model (DEM), field observations, and published and unpublished geochronological data (Siebe et al., 2014). Rectangles in broken lines indicate areas mapped in detail (Alberca de Guadalupe: Kshirsagar et al., 2015; El Caracol: Kshirsagar et al., 2016; W Zacapu: Reyes-Guzmán et al., 2018; Mazcuta near Comanja: Ramírez-Uribe et al., 2019). The legend of the map is shown in lower right. b) DEM showing some of the volcanoes mentioned in the text.

hazards, given the $\sim 77000$ inhabitants of the Zacapu municipality (INEGI, 2020; Reyes-Guzmán et al., 2021). It also hosts important archaeological sites of interest for constraining the development of pre-Hispanic civilizations in this formerly densely inhabited region (e.g., Michelet et al., 1989; Migeon, 1998; Arnauld and Faugère-Kalfon, 1998; Darras et al., 2017; Forest et al., 2019; Pereira et al., 2021).

Reyes-Guzmán et al. (2018) present a geological map, radiometric ages, and geochemical and petrographic data of the western sector of the Zacapu basin that includes Las Cabras volcano (Figure 2). They report the following: Most volcanoes are andesitic, accounting for 86 vol.\% of the products emitted during the last $2 \mathrm{Ma}$. Few dacitic volcanoes (4 vol.\%) and basaltic trachy-andesites, basaltic andesites, and rhyolites, were emitted by only one volcano, respectively. Andesites are porphyritic and contain up to $10 \mathrm{vol} . \%$ of phenocrysts that often show disequilibrium textures such as sieved plagioclases with resorbed margins and quartz with reaction coronas of augite microlites. The most recent eruptions (Mahgoub et al., 2018; Reyes-Guzmán et al., 2021) occurred during the Late Holocene, between 1500 BC and 
AD 900, forming closely-spaced viscous flows near to the basin (Malpaís Prieto, El Capaxtiro, Mesa La Víbora, Malpaís Las Víboras, and El Infiernillo). Las Cabras is part of a slightly older group of eruptions that occurred between 20 and 30 kyrs BP and formed a higher diversity of edifice types, including scoria cones with lavas (such as El Pueblito and El Molcajete), a tuff cone (Alberca de Los Espinos), and a small rhyolite dome (Las Pomas). Reyes-Guzmán et al. (2018) presented five radiocarbon ages on paleosols for Las Cabras that spread a notable range (27-32 cal kyrs BP), which will be further discussed below to refine the age of this eruption.

\section{METHODOLOGY}

During several field campaigns (2013-2015), products of Las Cabras were inspected and sampled. A morphological map of the volcano and its surroundings was made using field observations, satellite images (Google Earth 2020, 2021), a 5 m-resolution digital elevation model (DEM) constructed with data from Mexico's Instituto Nacional de Geografía, Estadística e Informática (codes: E14A11D1; E14A11D2; E14A11D3; E14A11D4; E14A11E1; E14A11E2; E14A11E3; E14A11E4; E14A11F1 y E14A11F3, scale: 1:10000; INEGI, 2016), and slope-maps built from the DEM. ArcMap software was used for calculating lava's areas and volumes (see details in Hernández Jiménez, 2016). The volume of the actual cone (the cone in its present shape), the pre-breaching cone (cone prior to breaching) and the hummocks (Table 1) was estimated from the DEM, with the surface difference tool of ArcMap GIS software ("DEM clipping"), following a condensed version of the methodology presented in Guilbaud et al. (2012), Larrea et al. (2017 and 2019b), and Ramírez-Uribe et al. (2019). This method requires to model the basal plane of the constructs, drawing contour lines that are consistent with the surrounding relief. For the actual cone, we used a slightly inclined surface that simulates the continuity of the slope of El Tule shield below the volcano. For the pre-breached cone, a circular shape was used to idealize the cone's dimensions as a symmetric closed crater cone or ring-shaped cone (Dóniz-Paéz, 2015). The difference between the actual cone and the pre-breaching cone provided an estimate of the volume of the breached sector. Finally, to obtain the volume of the hummocks, they were delineated from their morphology and their base was estimated from the altitude of the directly-surrounding lava surface. Two digital elevation models were then obtained (the DEM with hummocks and the DEM without), allowing to extract the volume of hummocks.

Exposed stratigraphic sections of the tephra fallout sequence at different distances from the volcano were studied in the field and samples collected from the distinct layers were sieved ( $\phi-6$ to 4 ) and observed below the optical microscope in the Laboratorio de Sedimentología Volcánica at the Instituto de Geofísica, Universidad Nacional Autónoma de México (UNAM). Sedimentary parameters

Table 1: Volume estimates for cone and hummocks made from DEM

\begin{tabular}{llr}
\hline Structure & Type & $\begin{array}{c}\text { Volume } \\
\left(\mathrm{m}^{3}\right)\end{array}$ \\
\hline $\begin{array}{l}\text { Las Cabras } \\
\text { Pre-breached cone }\end{array}$ & Aypothetic ring-shape cone & 74409053 \\
Breach & Difference between actual and hypothetic cones & 18916615 \\
Hummocks & High hummocks & 93325667 \\
& Small hummocks & 11677923 \\
& Total & 3211409 \\
& & 14889333 \\
\hline
\end{tabular}

were derived from frequency curves following Folk (1974). Thin sections of scoria, bomb, and lava samples were made by Mann Petrographics (New Mexico, USA) and studied below the petrographic microscope at UNAM. All the thin sections are described in Hernández Jiménez (2016). Modal analysis was performed for a sub-set of these samples using a point counter (see Hernández Jiménez, 2016 and Reyes-Guzmán, 2017). Bulk rock geochemical analyses of major and trace elements of a set of tephra and lava samples were conducted at Activation Laboratories (Canada), following the procedures summarized in Guilbaud et al. (2019) and presented in more detail on the webpage of the laboratory. Prior to plotting, major and minor element data were normalized to $100 \%$, after converting concentrations in $\mathrm{Fe}_{2} \mathrm{O}_{3}$ to $\mathrm{FeO}$ using $\mathrm{FeO}=0.8998^{\star} \mathrm{Fe}_{2} \mathrm{O}_{3}$.

\section{RESULTS}

\section{Cartography and morphological analysis}

Las Cabras volcano formed on the southern slopes of the El Tule shield, near its base (Figures 3 and 4). It consists of a breached scoria cone from which emerged lavas that followed the main topographic slope along a valley to the east, towards the Zacapu paleolake. The valley occupied by the flow is limited on its southern side by north-dipping lavas from El Tecolote shield (Figure 4). El Tule was dated by ${ }^{40} \mathrm{Ar} /{ }^{39} \mathrm{Ar}$ at $116 \pm 8 \mathrm{ka}$ and $\mathrm{El}$ Tecolote at $2 \pm 41 \mathrm{ka}$, suggesting a Late Pleistocene age for the latter (Reyes-Guzmán et al., 2018). The southern proximal margins of Las Cabras lavas are slightly overlapped by those from El Pueblito, a younger cone located upslope, while distal lavas are buried under Holocene lava flows from Mesa Las Víboras, El Capaxtiro, and Las Vigas (Figure 4). El Pueblito lavas are in turn overlapped by lavas of Mesa La Víbora. Ash from El Molcajete, a small breached scoria cone to the NE (Figure 3), covers Las Cabras fallout separated by a paleosol dated at $\sim 17$ cal kyrs BP (Reyes-Guzmán et al., 2018). Hence, the area surrounding this volcano was highly active after its formation, featuring five eruptions in a radius of $<7 \mathrm{~km}$ around the cone. Notably, most of the cones are breached, and their breach is oriented SE, towards the Zacapu basin (Figure 4).

Las Cabras cone is relatively large compared to other cones in this area. It is $170 \mathrm{~m}$ high, has a basal diameter of $1.09 \mathrm{~km}$, and a volume of $0.07 \mathrm{~km}^{3}$. Its construction on the slopes of El Tule shield creates a $45 \mathrm{~m}$ height difference between the upper and lower base of the cone that are $700 \mathrm{~m}$ distant. The cone's external slopes vary between $28^{\circ}$ and $48^{\circ}$, and present a regular erosive pattern made by $30-50 \mathrm{~m}$ spaced gullies. The breaching forms a $530 \mathrm{~m}$ wide $\mathrm{U}$-shaped opening in the cone that is oriented to the $\mathrm{N} 120^{\circ}$ (Figures 3 and 4). The missing cone volume is about $0.02 \mathrm{~km}^{3}$, hence $1 / 4$ of the actual cone.

We use the terminology of Guilbaud et al. (2005) to describe the lava products. The lava flow field reaches a length of $7 \mathrm{~km}$ and covers an area of $18.2 \mathrm{~km}^{2}$ with a bulk volume of $0.6 \mathrm{~km}^{3}$. These are minimum values because its margins are buried under younger lavas. The lava flow field shows a relatively simple structure that suggests two main stages of emplacement and flow direction: Lava first flowed to the $S$ and $\mathrm{E}$, forming a main lobe and then, to the $\mathrm{N}$ and $\mathrm{NE}$, forming an array of narrower secondary lobes fed by a channel (Figure 4). The main lobe (a on Figure 4) is thick, broad, with abundant compressional ridges that are perpendicular to flow direction, and has lobate and steep margins that raise 40 to $90 \mathrm{~m}$ above the surrounding ground, indicating significant yield strength and viscosity. The secondary lobes directly spread from an open channel that connects upflow to the cone breach and has compressional ridges in the center and discontinuous shear zones along the margins ( $\mathrm{b}$ and $\mathrm{c}$ on Figure 4). These lobes are buried to the $\mathrm{N}$ and $\mathrm{NE}$ under younger lavas from Malpaís La Víbora, 


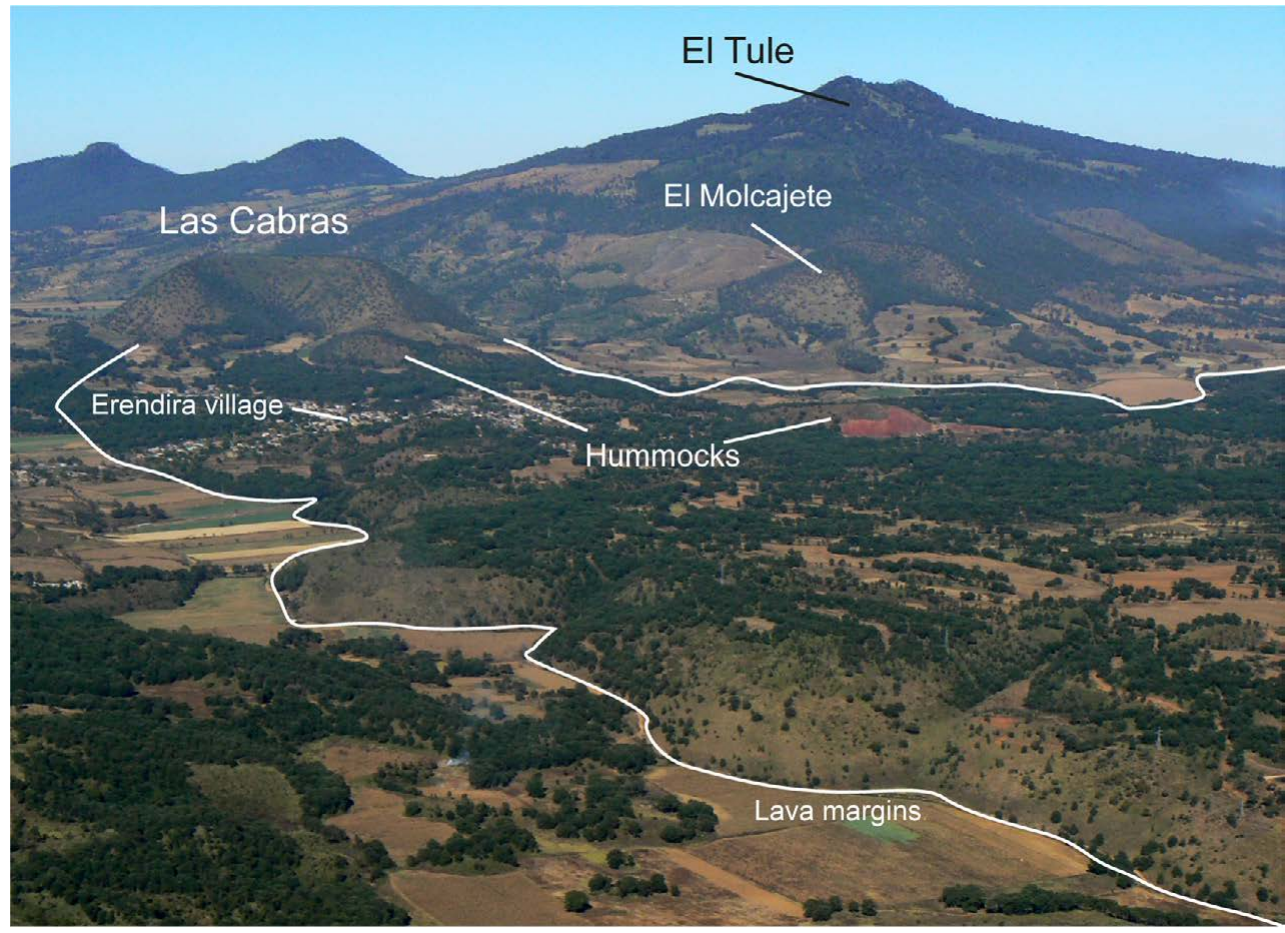

Figure 3. Aerial photograph of Las Cabras volcano and surrounding area. Note the position of Las Cabras and Cerro el Molcajete on the lower flanks of El Tule shield, and their breaching in the downslope direction. Las Cabras lavas (margins outlined by white line) have distinct elongated ridges that form hummocks, one of which is quarried displaying an oxide-reddish color in its interior. Photo taken from an airplane by C. Siebe in 2011, looking to the NW.

El Capaxitro, and Las Vigas (Figure 4). The southernmost of them flowed to the south, following closely the frontal margin of the main lobe until it stopped, meeting the prominent margins of El Tecolote's lavas (d on Figure 4). This lobe has lower-standing margins (40 m) than those of the main lobe and a relatively smooth surface, and was hence less viscous. It also features lobate relief marked by topography drops (Figure 4) that were described elsewhere as "down stepping" and "terrace-like" and attributed to lobe-by-lobe, tube-fed emplacement (Valentine et al., 2007).

Interestingly, the surface is strongly irregular across most of the lava flow. It features several-meter-high mounds and ridges that are easy to identify on the satellite image since they are forested, whereas the flatter surrounding grounds are mostly occupied by cultivated fields. These features are hummocks and further described below.

\section{Hummocks}

The lava features high hummocks with steep $\left(>40^{\circ}\right)$ margins and lower, less-steep ones, that are mostly located along the open-channel and elongated in the flow's direction (red and orange polygons on Figure 4). Their size generally decreases downflow. Their total volume is nearly 15 million $\mathrm{m}^{3}\left(0.015 \mathrm{~km}^{3}\right), 80 \%$ of which is made by the high hummocks (Table 1). The largest and highest hummock $\left(0.004 \mathrm{~km}^{3}\right)$ has a half-moon shape, is $670 \mathrm{~m}$ long, $<170 \mathrm{~m}$ wide, $60 \mathrm{~m}$ high, and stands just downflow of the cone's breach (e on Figure 4), seemingly pushed on the side by the flow and blocked by earlier lavas forming a lateral margin (f on Figure 4). Field observations at this site and at some mounds in the proximal part of the lava (283 and 284 on Figure 4) report an abundance of red agglutinates mixed with grey lava blocks. Quarries near the main road expose the interior of two large steepsided hummocks, slightly more downflow (281 and 282 on Figure 4). The hummock at site 281 is $430 \mathrm{~m}$ long, $<190 \mathrm{~m}$ wide, and $30 \mathrm{~m}$ high, while the one at site 282 is $300 \mathrm{~m}$ long, $<100 \mathrm{~m}$ wide, and $10 \mathrm{~m}$ high. Their interiors are distinctly red, and consist of crudely-layered, coarse deposits that contain partly-welded material including abundant bombs (Figure 5a). Bombs range from dense to highly vesicular, and commonly have elongated, fluidal shapes and vesicular banding (Figure 5b), as well as deep fractures and surface cracking, indicating intense shearing, degassing, and cooling during flight (Figure 5c). Some display a thin white coating that is concentrated along fracture surfaces (Figure 5c). A breadcrust bomb contained a light-grey finelyvesicular core with irregular flow-banding and a $\sim 2$-cm-thick, black, dense rind (Figure $5 \mathrm{~d}$ ). Other bombs have cores consisting of partly resorbed light-grey, dacitic xenoliths. One bomb was whitish and highly vesicular, with a sugary texture.

\section{Tephra fallout}

Las Cabras volcano produced thick, stratified pyroclastic deposits that are well exposed in multiple quarries at the base of the El Tule shield (blue dots in Figure 4). Four complete sections were analyzed in detail (Figure 6). They are located at 50, 500, 1600, and $3500 \mathrm{~m}$ from the vent, and range in thickness from $200 \mathrm{~cm}$ (distal site 295) to $900 \mathrm{~cm}$ (proximal site 279). The two most proximal sections were sampled thoroughly for granulometric and bulk compositional analysis, while fewer samples were taken from the two thinner, more distal ones (Figure 6). The ages of paleosol samples (published previously by Reyes-Guzmán et al., 2018) collected from these stratigraphic sections are reported in Figure 6.

\section{Granulometry and bedding thickness}

The tephra sequence can be subdivided into distinct layers based on their grain size, with marker beds that can be easily correlated between sections (Figure 6). We distinguish a basal, finer-grained lower unit (marker beds A to I) and a top, coarser-grained upper unit (marker beds J to O) (Figure 6), that are described separately in the following. 


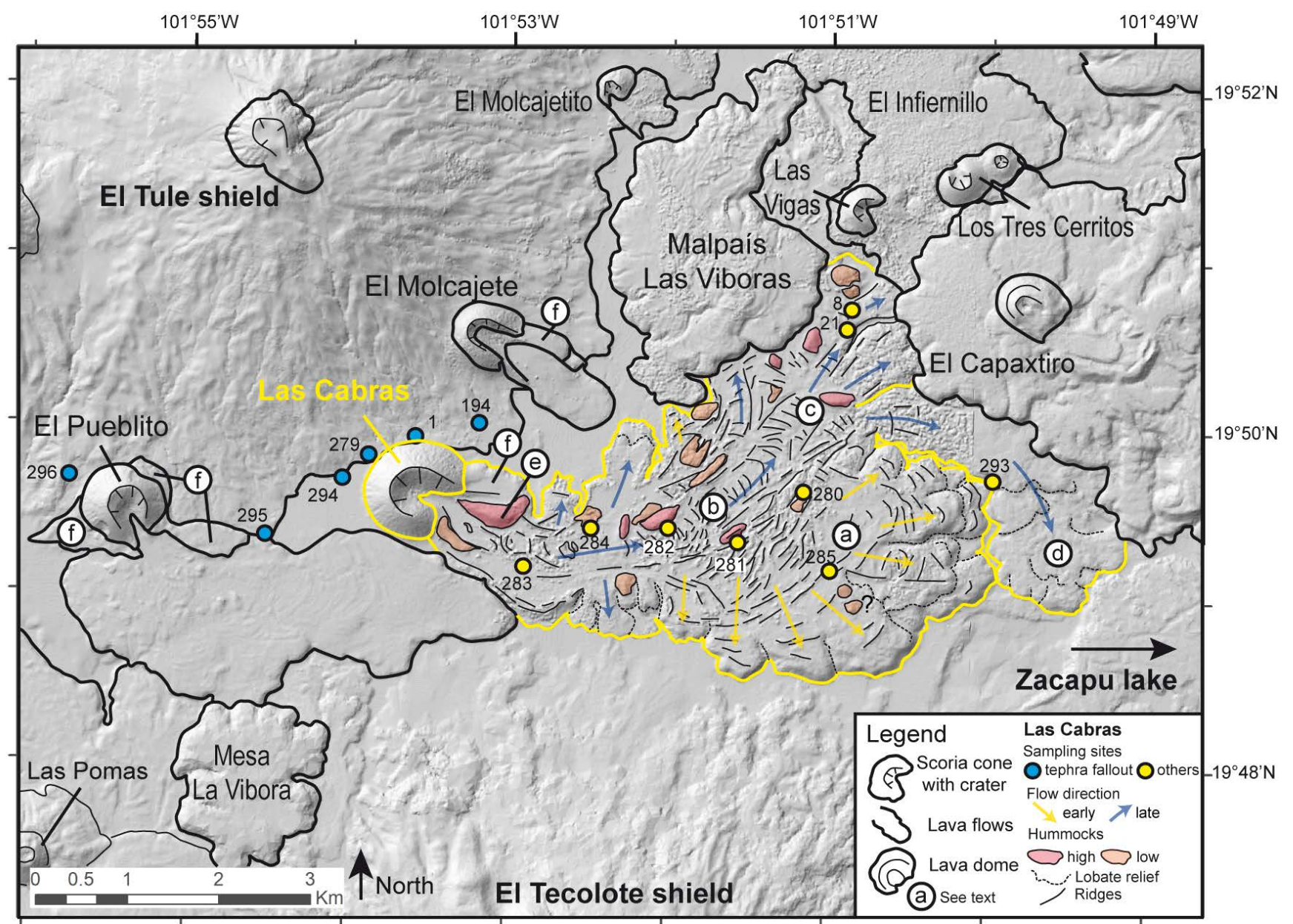

Figure 4. Map of Las Cabras volcano and surrounding area drawing the contours of the recent volcanoes on a 5-m-resolution shaded digital elevation model (DEM). Las Cabras scoria cone and lavas are delineated with a thick yellow line, and thin white lines highlight surface structures. Sampling locations are shown in yellow and blue circles. Small case letters refer to areas and features discussed in the text. Arrows indicate flow directions that were determined from the orientation of compressional ridges. Two main stages of emplacement were inferred (yellow, then blue). Note few imperfections of the DEM (irregular, rounded features) caused by the lack of correction for vegetation, which does not allow to map the debris avalanche material in detail. Question mark indicates uncertain identification of hummocks.

Note that the transition between both units occurs sharply. Bombs are common at close $(<500 \mathrm{~m})$ distances from the vent, and their size and abundance both increase vertically in these sections, but decrease overall with distance from the vent.

The lower unit consists of a stack of numerous thin, indurated, grey layers of fine to extremely-fine ash, alternating with slightly coarser and thicker brownish to light-grayish layers of medium-coarse to very-coarse ash (Figure 6). These two types of layers are strikingly similar in grain-size across the basal unit at each section. The finegrained layers $(\mathrm{C}, \mathrm{E}, \mathrm{G})$ are generally $<1 \mathrm{~cm}$-thick, poorly sorted (sorting coefficient $\sigma: 2.5-3.1$ ), and contain large amounts (>30 wt\%) of extremely fine ash $(\phi>4)$. The coarser-grained layers $(A, B, D, F$, $\mathrm{H}, \mathrm{I})$ are generally $>5 \mathrm{~cm}$ in thickness and better sorted ( $\sigma: 1.2-2.4)$. These layers decrease in median grain-size with distance from the vent.

The upper unit is distinctly coarser and composed of well-sorted, thick layers of fine-to-medium lapilli separated by thin fine-ash layers with faint boundaries and no internal bedding (Figure 6). At proximal sections 279 and 194, coarse layers have median grain sizes between 2 and $3 \phi$. They reach $1 \mathrm{~m}$ in thickness at section 279 , and $50 \mathrm{~cm}$ at section 194. At distal section 296 , they are $\sim 10 \mathrm{~cm}$ thick and have median grain-sizes of about $1 \phi$.

The transition between the lower and the upper units is marked by a couple of coarse layers (marker bed J) that present intermediate granulometric characteristics with a rather coarse mode but a long tail toward smaller grain-sizes, resulting in poor sorting (Figure 6).

\section{Clast types, xenoliths, and bombs}

The deposits are dominated by juvenile clasts ( $>90$ vol\%). These consist of scoria ranging from black to dark-brown, angular, and poorly vesicular to light-brown, sub-rounded to elongated, and highly vesicular. Dense clasts are microcrystalline and opaque, while vesicular ones are glassy and translucent. Vesicles are more abundant, larger $(<5 \mathrm{~mm})$ and coalesced in vesicular clasts compared to denser ones, where vesicles are few and small $(<0.5 \mathrm{~mm})$. The relative abundance of vesicular $v s$ dense scoria varies greatly between layers, with no systematic stratigraphic variation.

Accidental lithics are of two main types: 1) White to light-grey, finely-vesicular clasts, some with vesicular banding, and 2) oxidized, reddish, dense clasts with few and small vesicles $(<1 \mathrm{~mm})$. The lightgrey clasts are abundant, both in coarse and fine-grained layers of the top unit. Some red clasts were also observed in the basal unit and rare whitish scoriaceous clasts also occur.

Similar to bombs in hummocks, those found in the tephra sections commonly present vesicular banding. Some bombs have elongated 

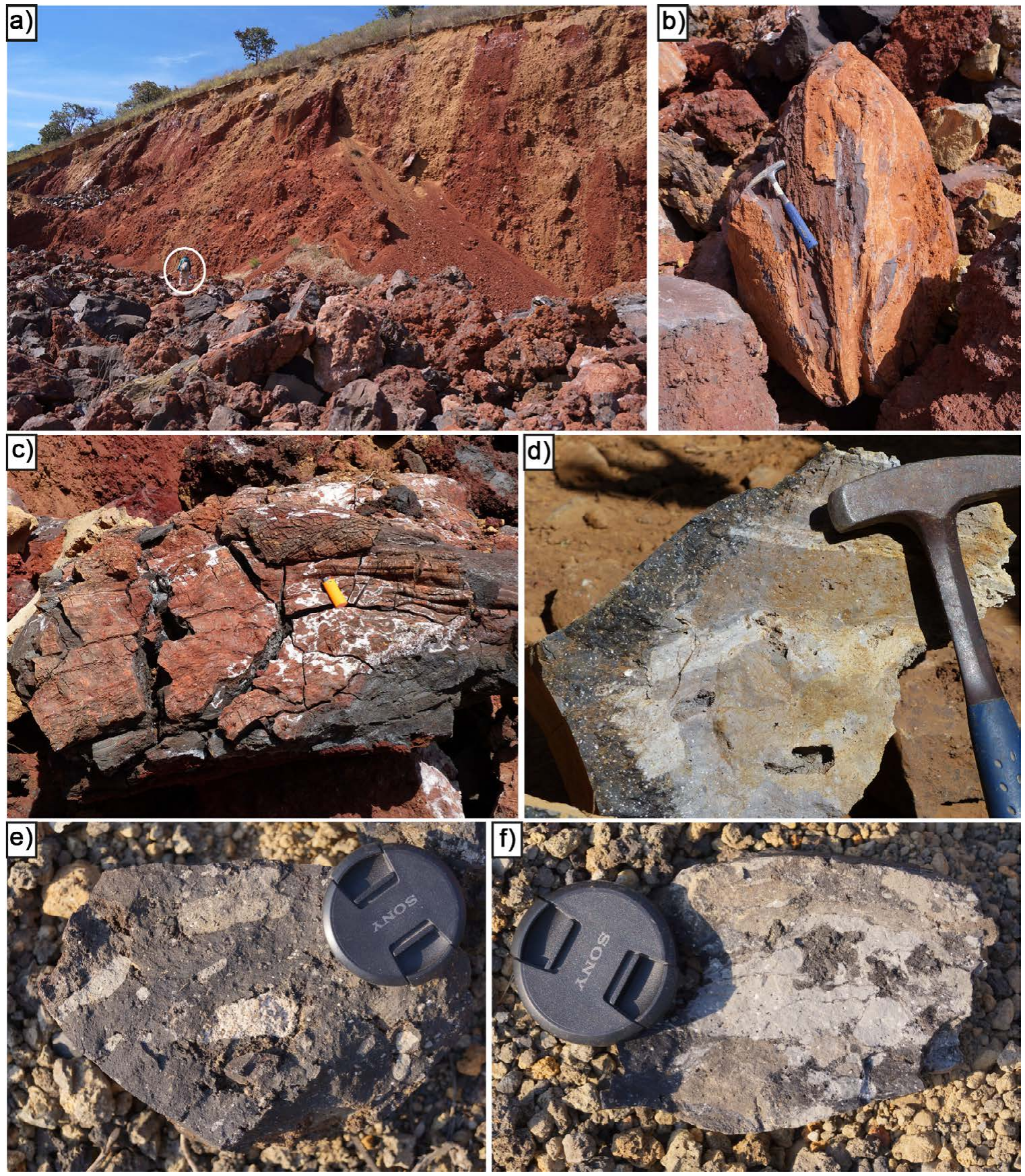

Figure 5. Hummocks and bombs. Photographs of main features. a) Photograph of quarry into main hummock at site 281 (see Figure 4). Note the oxidized red color of the vertical quarry wall that reflects the abundance of agglutinates, and the numerous large bombs left at the base of the quarry wall, because of their lack of commercial value. Circle indicates a person for scale. b) Large bomb with fusiform shape that evidences inflight deformation of fluid magma. c) Large bomb with intense fracturing and white hydrothermal coating. d) Interior of bomb with xenolithic, light-grey, finely-vesicular core and dark glassy rim. Petrographic analysis shows that the core and the rim have a similar mineralogy and only differ by vesicle content. Hence the dark rim is a quenched margin. e) Bomb from fallout that contains dacitic xenoliths showing clear rounded edges. f) Bomb from fallout that contains dacitic xenoliths showing convoluted, diffuse contact with the andesitic juvenile matrix.

shapes while others are intensely fractured and have angular shapes. Few are thoroughly dense, and present rounded shapes. Some dense bombs from the upper unit present fractured, dense rinds, and vesicular cores made of banded light-grey material. Such light-grey material is common in the bombs, where it displays highly variable shapes ranging from thin wedge-shaped lenses (schlieren) to angular, rounded, or convoluted blocks (Figures $5 \mathrm{e}$ and $5 \mathrm{f}$ ). The contact of these xenoliths with the surrounding dark grey juvenile material is either sharp (Figure $5 e$ ) or diffuse (Figure 5f). In some bombs, the light-grey material is disseminated in the matrix.

\section{Deformation and erosion features}

All sections present clear evidence for syn-eruptive erosion and deformation. In proximal sections 279 and 194, tephra layers are 

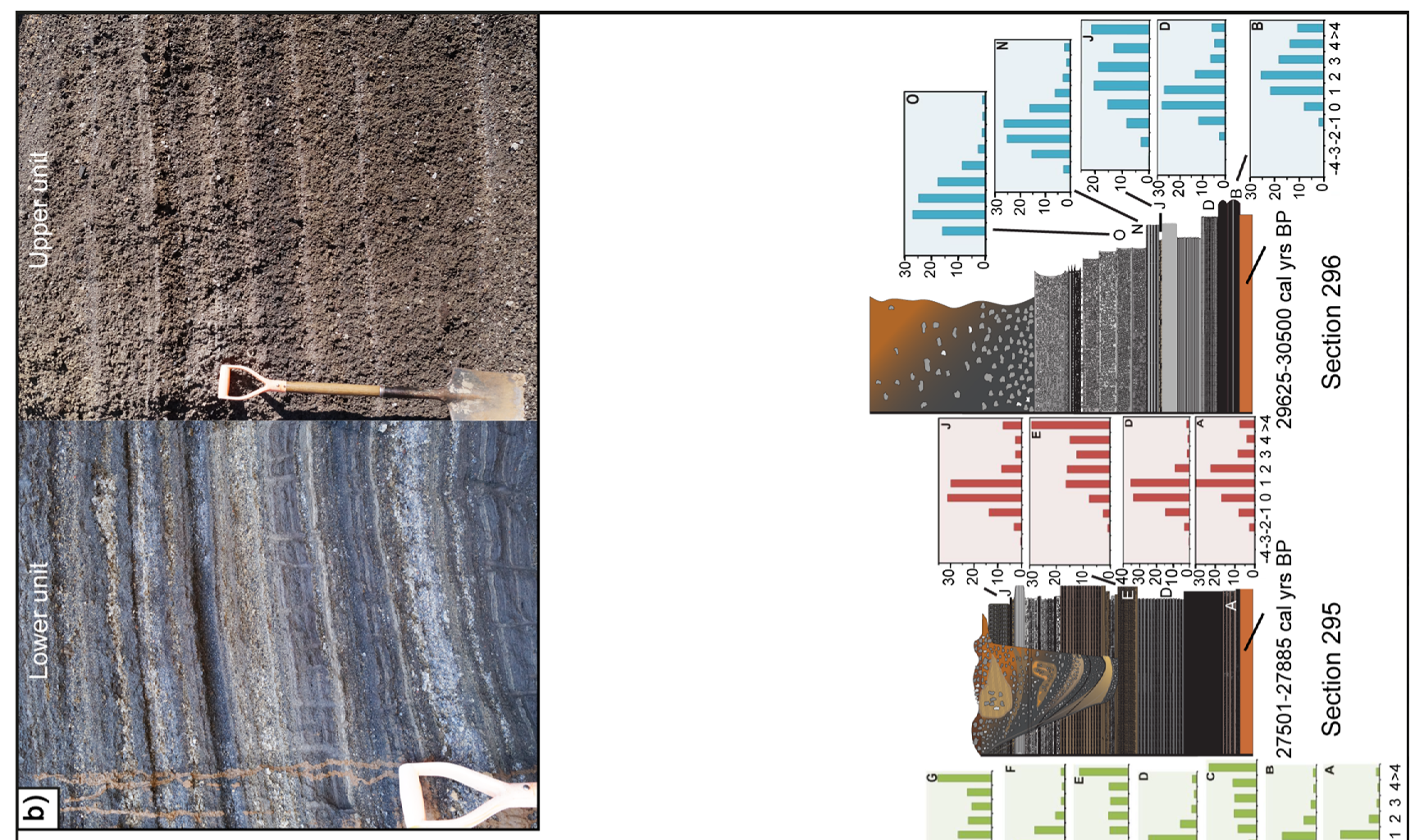

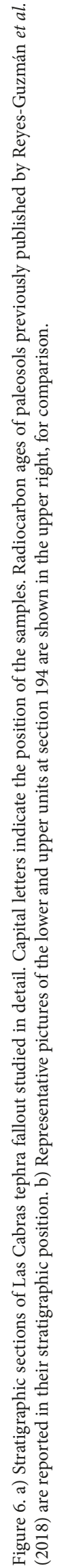

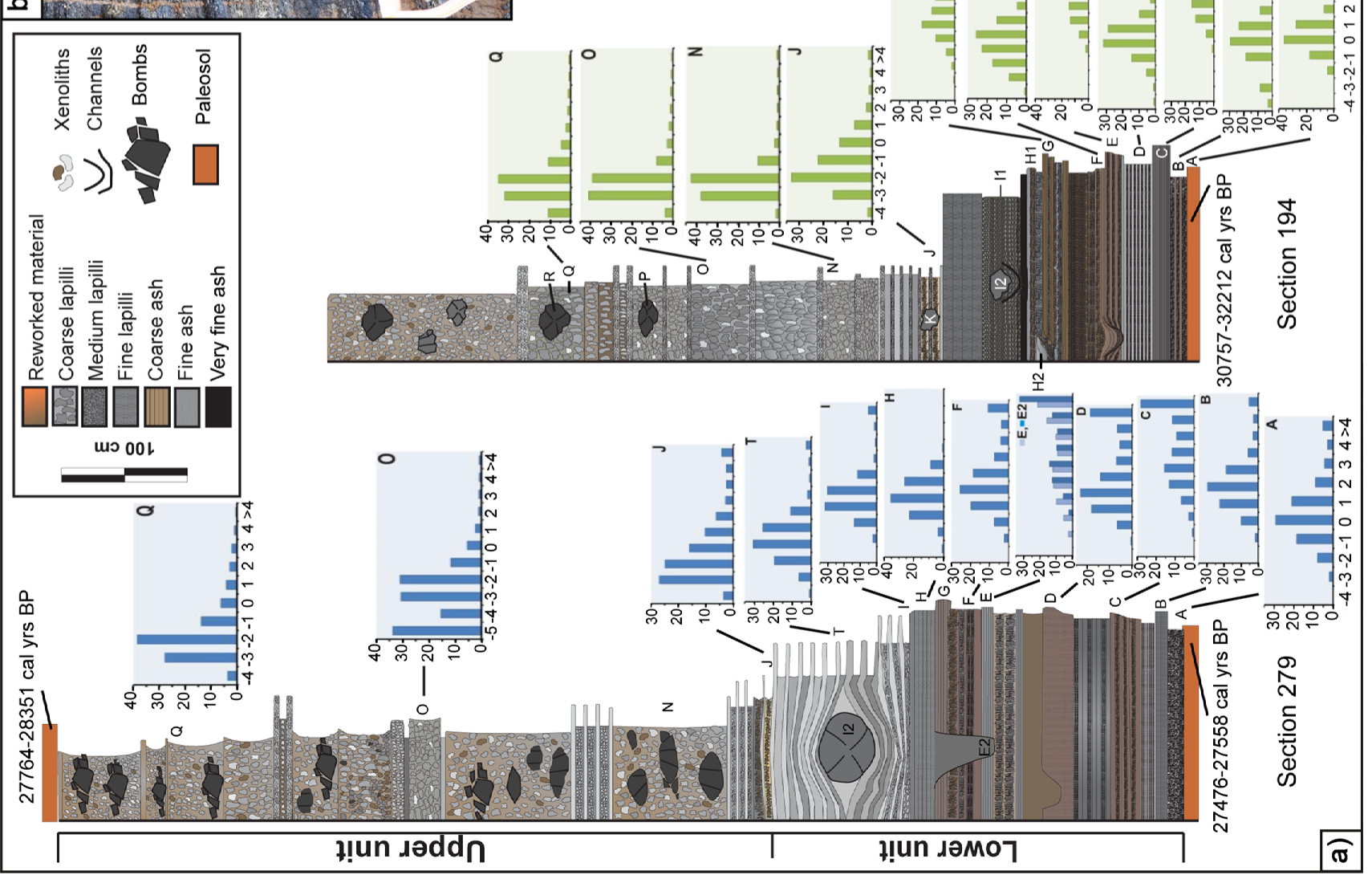


affected by significant plastic and fragile deformation. At both sites, the stratification displayed a marked inclination, reflecting the slope of the pre-eruptive substrate formed by the El Tule lava shield.

The most abundant structures in the lower unit of both sections are erosional channels. These channels mostly affect thick packages of fine-grained layers (C, E, and G marker beds). At site 194, they are surprisingly uniform, measuring 10 to $18 \mathrm{~cm}$ deep and 30 to $40 \mathrm{~cm}$ wide with a regular horizontal spacing at 80 to $100 \mathrm{~cm}$ intervals. They also tend to be vertically aligned (Figure 7a). They cut sharply into the ash layers, and tend to be asymmetric with one side that is nearly vertical and step-shaped, and the other side having a low and gradual dip (Figures 7a and 7b). The channels are filled with wedge-shaped stratified, coarser beds that were deposited subsequently, draping over the depression and progressively flattening the topography (Figures $7 \mathrm{a}$ and $7 \mathrm{~b}$ ). Interestingly, similar features were observed at $\mathrm{mm}$-scale, on a thin-section made across a package of indurated ash layers intersected laterally by a channel at section 279 (Figure 7c).

The predominant type of deformation in the upper unit of both sections was caused by large bombs that created impact sags (soft deformation) and were mantled by subsequent deposits. Their abundance at proximal site 279 creates pronounced undulations in the layers (Figure $7 \mathrm{~d}$ ). Large bombs fragmented upon impact, forming strings of angular blocks with jigsaw-fit structure (Figure 7d). At section 194, the impact of a large bomb compacted and crushed the coarse lapilli layers directly below, and created semi-vertical normal faults in the fine-grained layers of the lower unit further underneath (Figure 7e). Such impacts also caused the folding over of the lapilli layers located behind, evidencing plastic deformation (Figure $7 \mathrm{f}$ ).

The more distal sections $(295,296)$ also display deformation structures. At site 295, the finely-stratified layers of the lower unit are dissected by $\sim 1 \mathrm{~m}$ deep channels with vertical sidewalls. These are filled with cross-stratified organic soil, blocks of stratified ash from the basal unit, and lapilli layers from the top unit, which are either mixed or intercalated. At section 196, the most distal from the vent, fine-ash layers of the lower unit display fine-scale cross-stratification and $\mathrm{cm}$-deep channels. The layers of the upper part of this unit are locally dissected by up to $80 \mathrm{~cm}$-deep and tens of $\mathrm{cm}$-wide channels with sharp, vertical sidewalls, that are filled with stratified, altered lapilli from the upper stratigraphic unit.

\section{Petrography}

A wide range of samples was studied petrographically using thin-sections. These included juvenile scoria from different levels of the proximal tephra fallout sections (some manually separated into vesicular and dense prior to thin-section preparation), different types of bombs (many enclosing xenoliths and/or presenting mingling textures), and accidental lithics that were collected from hummocks and the upper fallout unit, and lava blocks at different distances from the vent. In this context, the so-called mingling texture refers to the presence of light-grey bands in the rock. Results from the modal analyses of selected thin-sections are reported in Table 2 and described below, along with microtextural characteristics.

All samples display a poorly porphyritic texture, with low phenocryst contents $(<5$ vol\%) and variable amounts of groundmass crystals (6-81 vol\%) in a glassy to microcrystalline matrix (Table 2 ). Vesicle content varies and is lowest in two lava samples, ranging from 12 to 32 vol\% in scoria, and 7 to 34 vol\% in bombs (Table 2). Vesicular and dense scoria clasts have similar mineralogy, yet the first type presents a higher content of small plagioclase laths. Phenocrysts $(1-2 \mathrm{~mm})$ are mainly plagioclase $(\mathrm{Pl})$ and olivine $(\mathrm{Ol})$, which are also present as groundmass crystals $(<1 \mathrm{~mm})$, along with oxides $(\mathrm{Ox})$ and, sometimes, pyroxene $(\mathrm{Px})$ which includes both augite and hypersthene according to Reyes-Guzman et al. (2018). While Pl and Ol occur in comparable proportions as phenocrysts, Pl largely dominates in the groundmass. Biotite $(\mathrm{Bt})$ is rare and low in abundance $(<1 \mathrm{vol} \%)$ and was exclusively found in light-grey lava blocks, bombs, and xenoliths where it forms dispersed small phenocrysts with euhedral lath-shapes to anhedral rounded blobs. A white scoriaceaous clast contained quartz, K-Feldspar, and Pl.

Upper scoria units have higher abundance in Ol than basal ones. Scoria clasts from the lower unit of section 279 present oxidized margins with an opaque groundmass and abundant Ox microphenocrysts (0.1-0.4 vol\%, Table 2). These features were not observed in other sections and probably result from post-depositional weathering.

Modal percentages are similar for all lava samples, except for sample 293 from the thinner, secondary lobe at furthest distance from the vent (d in Figure 4) that has distinctly higher Ol-contents, both as phenocrysts and groundmass crystals.

Phenocrysts $(>1 \mathrm{~mm})$ and microphenocrysts $(0.1-1 \mathrm{~mm})$ display disequilibrium textures in all samples. Ol phenocrysts occur as rectangular, rounded, or skeletal (arrow-shaped) crystals with Cr-spinel inclusions and embayments, and sometimes surrounded by a reaction corona made of $\mathrm{Pl}$ laths. Pl phenocrysts also commonly display signs of corrosion, such as rounded rims and sieved cores, internal zoning, and inclusions in some cases. These features are common in the area (see text and figs. 8e and 8 f of Reyes-Guzmán et al., 2018). Some Bt and Px also present corroded cores and zoning. Ol crystals are often grouped in $\sim 1 \mathrm{~mm}$-sized clusters, sometimes associated with $\mathrm{Pl}$ and Px. Bt is sometimes intergrown with $\mathrm{Pl}$.

Xenoliths in bombs present a wide variety of sizes ( $\mathrm{mm}$ to $\mathrm{cm}$ ), textures, mineral assemblages, and shapes. They may be vesicular or dense, rounded in shape or angular. They are typically crystal-rich and often present abundant $\mathrm{Pl}$ that may be associated with $\mathrm{Ol}$, less often $\mathrm{Ox}$, and $\mathrm{Bt}$ in light-grey clasts. They often have high amounts of opaque minerals and tend to be associated with large coalesced vesicles. The darker rims of some large, light-grey bombs only differ from their interior by their low vesicularity (they display the same minerals), indicating that they originated by quenching, and hence that the xenolithic bombs were erupted hot, and vesiculated late, during flight.

\section{Geochemistry}

Bulk compositional analyses for Las Cabras samples are reported in Table 3 and some representative elements are plotted in Figure 8. All products are calc-alkaline. Juvenile products vary from basaltic andesite to andesite (54-62 $\mathrm{wt} \% \mathrm{SiO}_{2}$ ). Samples from the upper tephra unit (late tephra) spread this whole range, while lavas and samples from the lower tephra unit (early tephra) spread over a more restricted range (57-61 wt\%) (Figure 8). Samples with light-grey Bt-bearing material are dacitic (63-67 wt $\% \mathrm{SiO}_{2}$ ) and their $\mathrm{SiO}_{2}$ content increases linearly with the proportion of xenolithic material in them, following straight mixing lines in bimodal graphs (Figure 8).

Juveniles present good, linear negative correlations of $\mathrm{FeO}, \mathrm{CaO}$, and $\mathrm{TiO}_{2}$ with $\mathrm{SiO}_{2}$, and a positive correlation of $\mathrm{K}_{2} \mathrm{O}$ with $\mathrm{SiO}_{2}$ (Figure 8). Plots of $\mathrm{MgO}, \mathrm{Al}_{2} \mathrm{O}_{3}, \mathrm{Na}_{2} \mathrm{O}, \mathrm{P}_{2} \mathrm{O}_{5}$, and $\mathrm{MnO}$ versus $\mathrm{SiO}_{2}$ show more scatter. Notably, samples from the lowermost tephra layers (A and B) have distinctly lower $\mathrm{MgO}$, higher $\mathrm{Al}_{2} \mathrm{O}_{3}, \mathrm{Na}_{2} \mathrm{O}, \mathrm{P}_{2} \mathrm{O}_{5}$, and $\mathrm{MnO}$, lower $\mathrm{Ni}$ and higher $\mathrm{Sr}$ compared to other samples with similar $\mathrm{SiO}_{2}$ (Figure 8). We note that these samples contain high amounts of $\mathrm{Pl}$ phenocrysts with disequilibrium textures, which could explain their distinct composition.

$\mathrm{MgO}$ is perfectly correlated with $\mathrm{Ni}\left(\mathrm{R}_{2}=0.9\right)$ and $\mathrm{Cr}$ for all samples. There is a broad linear decrease in $\mathrm{Ni}$ and $\mathrm{MgO}$ with stratigraphic height in the tephra sections (Figure 9), but other elements show 

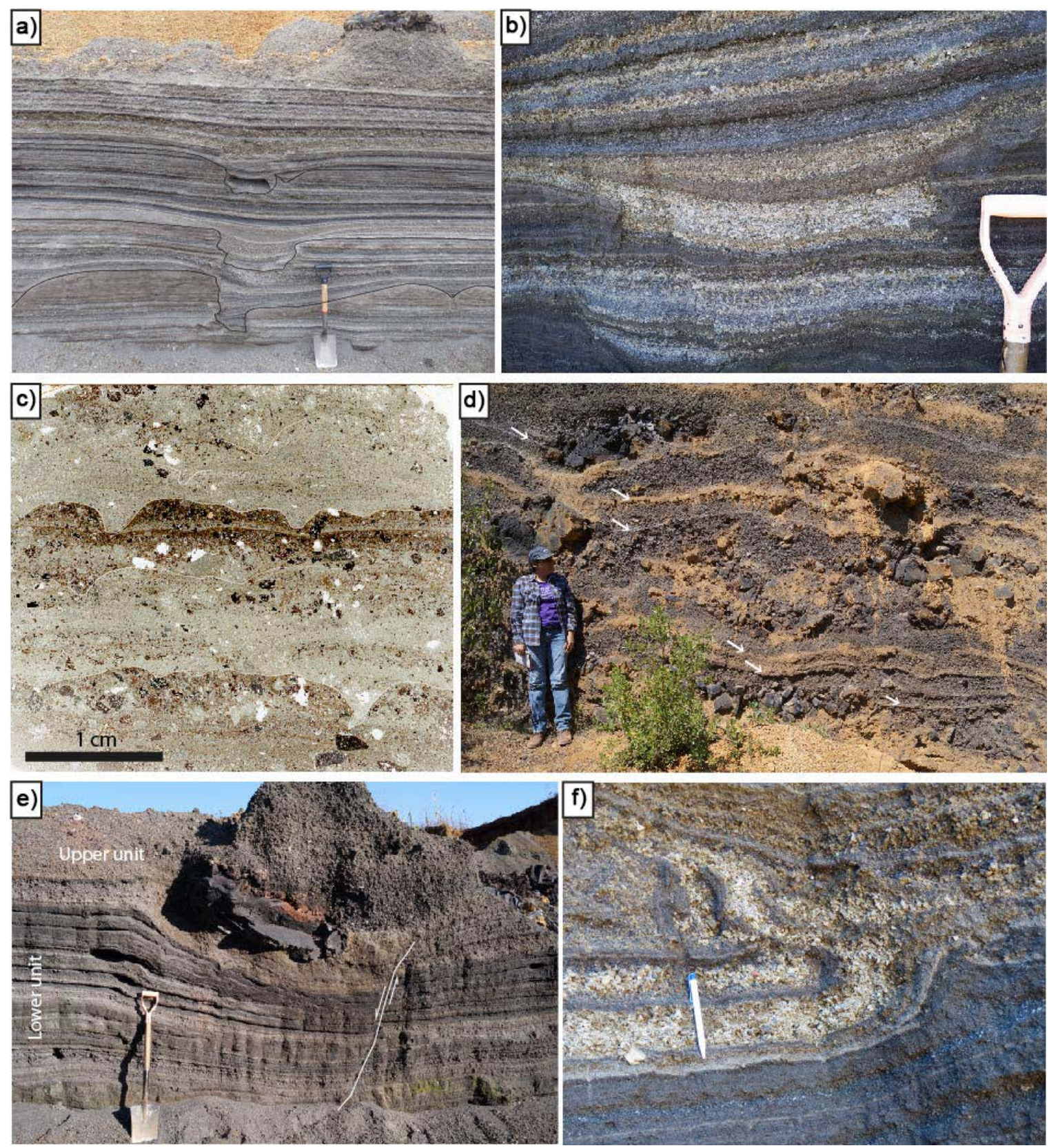

Figure 7. Deformation and erosion structures in Las Cabras tephra fallout deposits. a) Asymmetric erosional channels affecting several levels of the lower fallout unit at site 194. Thin black lines highlight the erosional scars. Note the vertical alignment of three main channels at that specific location. b) Close-up picture of the central part of an erosional channel filled by coarse layers. c) Scan of a thin-section made from an indurated package of ash layers from the lower unit (sample 194G). Main erosional channels are highlighted by a white line. Note that they seem to correlate with oxidized levels. Also note vesicles in ash layers. d) Photograph of the upper unit of proximal section 279 that consists of coarse layers rich in juvenile bombs, most of which fragmented upon impact, interbedded with thin ash layers (see arrows) that display pronounced undulations due to bomb impacts and subsequent mantling. Person for scale is $1.6 \mathrm{~m}$ high. e) Photograph of impact structures caused by the landing of a large juvenile bomb on the lower unit at site 194. Note the sagging of the fine-grained layers and the formation of a distinct normal fault that causes a $7 \mathrm{~cm}$ vertical displacement. f) Photograph of the plastic deformation that affected coarse lapilli layers (marker bed J) behind the large bomb-impact featured in e.

scatter or no significant change. We note that samples from the lower unit of section 279 are abnormally enriched in La and other light Rare Earth Elements (light-REE), which is not observed in other sections (Figure 9), and is correlated with a higher degree of oxidation of the scoria. The quarry wall where these samples were collected was buried at the base by reworked soil, loose ash and scoria, and higher-up, it was coated by a thin layer of mud resulting from water runoff. As all REE and in particular light-REE elements are mobile in fluids, we infer that this impregnation by fluids significantly altered the clasts from the lowermost tephra layers, especially those near contact with the impermeable paleosol, and caused their oxidation and enrichment in mobile elements. We note however that such alteration did not affect major element concentrations. Such effect may be relatively common; however, we are not aware of other studies that report it.

Except for those samples, all lava and tephra samples spread a rather small range in trace elements. Dacitic xenoliths have slightly 
higher concentrations in less compatible elements (Cs, Rb, Ba, Th, $\mathrm{Ta}$ ) and lower concentrations in more compatible ones (medium and heavy-REE; Sr), with negative anomalies in P and Ti. All samples have arc-type trace element patterns with negative anomalies in $\mathrm{Nb}$ and $\mathrm{Ta}$ and relative enrichment in light-REE in comparison to heavy-REE.

\section{INTERPRETATION AND DISCUSSION}

Las Cabras is a simple, horseshoe-shaped volcano that is morphologically similar to many others in the MVGF. However, it presents several particularities that shed light on the processes that can operate during monogenetic eruptions and their related hazards.

\section{Eruption age, size, chronology and eruptive style}

The age of the eruption can be refined by revisiting the existing paleosol dates (Reyes-Guzman et al., 2018). Three of these have similar overlapping age ranges (27.5-28.3 cal kyrs BP) while the two others are older by 2000 to 5000 yrs (29.5-32 kyrs BP). The older ages can be attributed to slope-driven pre-eruptive surface erosion that exposed older deeper parts of the soils that then were covered by the tephra. Given that paleosols are older than the overlying tephra deposits and because of the long time-lapse for soil formation, we prefer the younger ages and estimate that the eruption took place between 26 and 27 kyrs BP.

In terms of size, Las Cabras scoria cone height $(170 \mathrm{~m})$, lava flow length $(>7 \mathrm{~km})$, and total erupted volume $\left(>0.6 \mathrm{~km}^{3}\right)$ are higher than median values for scoria cones in the MGVF $\left(90 \mathrm{~m}, 3 \mathrm{~km}\right.$, and $0.2 \mathrm{~km}^{3}$, respectively, according to Hasenaka and Carmichael, 1985). Hence, the eruption was relatively large in magnitude and possibly long-lasting (Porter 1972). The decade-long eruptions of Jorullo and Paricutin emit- ted comparable volumes of lava (Guilbaud et al., 2009) but constructed higher cones (220 and $290 \mathrm{~m}$, respectively), implying that the explosive activity was more intense and probably also lasted longer. Lavas at Las Cabras nevertheless reached longer distances $(>7 \mathrm{~km})$ than at Jorullo and Paricutin $(\sim 5 \mathrm{~km})$, which seems to be related to their constriction in a valley, since they had similar bulk compositions and hence viscosity. The simpler morphology of Las Cabras lavas in comparison to the complex lava field erupted at Jorullo and Paricutin, indicates a more continuous lava output.

Stratigraphic evidence shows that the eruption of Las Cabras was initially mainly explosive, emitting ash, lapilli, and bombs building a large cone and depositing tephra fallout, and then dominantly effusive, forming the lava flow. Both activities were however probably simultaneous at some stage. There are not any major erosional discontinuities in the tephra sequence and there is no evidence for a vertical stacking of distinct flow units (that would indicate pauses in the lava output), thus, both the explosive and effusive activity must have been continuous. The early explosive activity alternated between strong explosions generating layers of dense and fine ash, and weaker explosions producing coarser and more vesicular scoria (early tephra), indicating variable magma and gas flux in the conduit or the occurrence of several vents acting at the same time, as observed at Paricutin (Foshag and González-Reyna, 1956). A significant decrease in explosivity with time is marked by an increase in tephra coarseness and bomb abundance in the stratigraphy. This weakening in the activity was probably associated with simultaneous lava emission from the base of the cone, as also observed at Paricutin (Foshag and González-Reyna, 1956).

The lavas first spread to the south and southeast, filling a preexisting valley with a broad and viscous, thick (40-90 m) lava lobe.

Table 2. Modal analyses of selected thin sections.

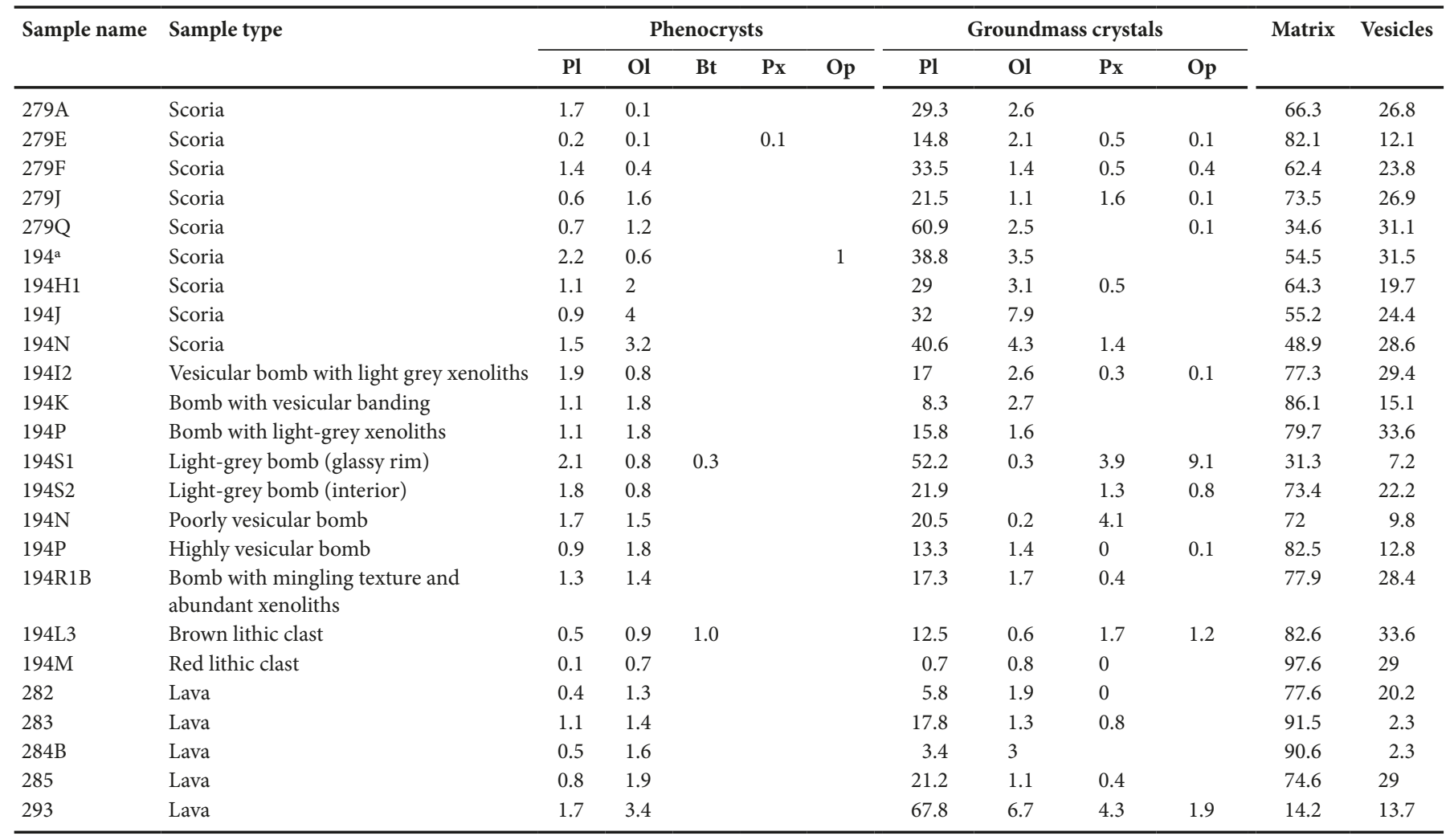

Crystal and matrix proportions are in vol. \%, normalized on a vesicle-free basis (total vol. minus vesicle vol.). 
The resulting relief inversion was the probable cause for a shift in the main flow direction to the $\mathrm{N}$ and NE, which formed an array of laterally-emplaced, narrow lava lobes fed from the vent through an open-channel. The distinct morphology of these lobes compared to the earlier-emplaced, main lobe suggest a decrease in lava viscosity, which may be due to a change in magma composition. The last eruptive event is related to the cone collapse and formation of large hummocks on the lava, which will now be discussed more extensively.

\section{Hummock formation}

Las Cabras lavas are covered by large hummocks made of thick piles of agglutinates and large bombs which, from their characteristics, must have formed by the landing of hot and large pyroclasts very close to the vent, and hence originated from the cone's interior (Holm, 1987). Some bombs contain dacitic material that appear only in the upper tephra unit, indicating that the collapse took place late in the eruption sequence. The largest and steepest hummocks preserve primary

Table 3. Bulk rock compositions. Major elements (oxides) in wt. \%, trace elements in ppm.

\begin{tabular}{|c|c|c|c|c|c|c|c|c|c|c|c|c|c|c|c|c|}
\hline \multirow{2}{*}{$\begin{array}{l}\text { Sample } \\
\text { name }\end{array}$} & \multicolumn{16}{|c|}{ Tephra fallout $(1 / 3)$} \\
\hline & $194 \mathrm{~A}$ & $194 \mathrm{~B}$ & $194 \mathrm{D}$ & $194 \mathrm{~F}$ & $194 \mathrm{H} 1$ & $194 \mathrm{H} 2$ & $194 \mathrm{I} 1$ & $194 \mathrm{I} 2$ & $194 \mathrm{~J}$ & $194 \mathrm{~K}$ & $194 \mathrm{~N}$ & 1940 & $194 \mathrm{P}$ & 194Q & $295 A$ & 295D \\
\hline $\begin{array}{l}\text { Lat N19 } \\
\text { Long W101이 }\end{array}$ & $\begin{array}{l}50^{\prime} 00.2^{\prime \prime} \\
53^{\prime} 10.5^{\prime \prime}\end{array}$ & $\begin{array}{l}50 ' 00.2^{\prime \prime} \\
53^{\prime} 10.5^{\prime \prime}\end{array}$ & $\begin{array}{l}50^{\prime} 00.2^{\prime \prime} \\
53^{\prime} 10.5^{\prime \prime}\end{array}$ & $\begin{array}{l}50^{\prime} 00.2^{\prime \prime} \\
53^{\prime} 10.5^{\prime \prime}\end{array}$ & $\begin{array}{l}50^{\prime} 00.2^{\prime \prime} \\
53^{\prime} 10.5^{\prime \prime}\end{array}$ & $\begin{array}{l}50^{\prime} 00.2^{\prime \prime} \\
53^{\prime} 10.5^{\prime \prime}\end{array}$ & $\begin{array}{l}50^{\prime} 00.2^{\prime \prime} \\
53^{\prime} 10.5^{\prime \prime}\end{array}$ & $\begin{array}{l}50^{\prime} 00.2^{\prime \prime} \\
53^{\prime} 10.5^{\prime \prime}\end{array}$ & $\begin{array}{l}50^{\prime} 00.2^{\prime \prime} \\
53^{\prime} 10.5^{\prime \prime}\end{array}$ & $\begin{array}{l}50^{\prime} 00.2^{\prime \prime} \\
53^{\prime} 10.5^{\prime \prime}\end{array}$ & $\begin{array}{l}50^{\prime} 00.2^{\prime \prime} \\
53^{\prime} 10.5^{\prime \prime}\end{array}$ & $\begin{array}{l}50^{\prime} 00.2^{\prime \prime} \\
53^{\prime} 10.5^{\prime \prime}\end{array}$ & $\begin{array}{l}50^{\prime} 00.2^{\prime \prime} \\
53^{\prime} 10.5^{\prime \prime}\end{array}$ & $\begin{array}{l}50^{\prime} 00.2^{\prime \prime} \\
53^{\prime} 10.5^{\prime \prime}\end{array}$ & $\begin{array}{l}49^{\prime} 23.6^{\prime \prime} \\
54^{\prime} 29.2^{\prime \prime}\end{array}$ & $\begin{array}{l}49^{\prime} 23.6^{\prime \prime} \\
54^{\prime} 29.2^{\prime \prime}\end{array}$ \\
\hline Sample type & $\begin{array}{l}\text { bulk } \\
\text { scoria }\end{array}$ & $\begin{array}{l}\text { bulk } \\
\text { scoria }\end{array}$ & $\begin{array}{l}\text { bulk } \\
\text { scoria }\end{array}$ & $\begin{array}{l}\text { bulk } \\
\text { scoria }\end{array}$ & $\begin{array}{l}\text { bulk } \\
\text { scoria }\end{array}$ & $\begin{array}{l}\text { bulk } \\
\text { scoria }\end{array}$ & $\begin{array}{l}\text { bulk } \\
\text { scoria }\end{array}$ & $\begin{array}{c}\text { bomb } \\
\text { with } \\
\text { xenolith }\end{array}$ & $\begin{array}{l}\text { bulk } \\
\text { scoria }\end{array}$ & bomb & $\begin{array}{l}\text { bulk } \\
\text { scoria }\end{array}$ & $\begin{array}{l}\text { bulk } \\
\text { scoria }\end{array}$ & $\begin{array}{c}\text { bomb } \\
\text { with } \\
\text { xenolith }\end{array}$ & $\begin{array}{l}\text { bulk } \\
\text { scoria }\end{array}$ & $\begin{array}{l}\text { bulk } \\
\text { scoria }\end{array}$ & $\begin{array}{l}\text { bulk } \\
\text { scoria }\end{array}$ \\
\hline $\mathrm{SiO}_{2}$ & 58.83 & 58.06 & 60.17 & 59.13 & 59.97 & 60.05 & 59.45 & 59.68 & 58.56 & 60.65 & 56.16 & 57.33 & 58.97 & 56.15 & 58.75 & 58.00 \\
\hline $\mathrm{TiO}_{2}$ & 0.97 & 0.96 & 0.77 & 0.91 & 0.83 & 0.80 & 0.83 & 0.82 & 0.84 & 0.75 & 0.93 & 0.93 & 0.86 & 0.98 & 0.96 & 0.89 \\
\hline $\mathrm{Al}_{2} \mathrm{O}_{3}$ & 17.78 & 18.08 & 16.58 & 17.11 & 16.36 & 16.23 & 16.33 & 16.23 & 15.58 & 15.51 & 16.57 & 15.98 & 15.92 & 16.68 & 17.50 & 16.60 \\
\hline $\mathrm{Fe}_{2} \mathrm{O}_{3}(\mathrm{~T})$ & 6.68 & 6.87 & 5.92 & 6.26 & 5.89 & 5.92 & 6.17 & 6.09 & 6.51 & 5.94 & 7.09 & 6.92 & 6.25 & 7.22 & 7.66 & 7.34 \\
\hline $\mathrm{MnO}$ & 0.13 & 0.13 & 0.12 & 0.12 & 0.12 & 0.12 & 0.12 & 0.12 & 0.12 & 0.12 & 0.13 & 0.13 & 0.12 & 0.13 & 0.13 & 0.13 \\
\hline $\mathrm{MgO}$ & 3.56 & 3.81 & 4.65 & 4.51 & 5.08 & 5.15 & 5.24 & 5.22 & 6.05 & 5.17 & 6.59 & 6.18 & 5.69 & 6.51 & 3.73 & 4.69 \\
\hline $\mathrm{CaO}$ & 6.26 & 6.48 & 6.15 & 6.19 & 6.04 & 6.03 & 6.06 & 6.03 & 7.09 & 6.21 & 7.38 & 7.36 & 6.56 & 7.31 & 6.43 & 6.37 \\
\hline $\mathrm{Na}_{2} \mathrm{O}$ & 4.03 & 4.00 & 3.75 & 3.88 & 3.73 & 3.73 & 3.80 & 3.82 & 3.52 & 3.61 & 3.54 & 3.51 & 3.71 & 3.42 & 3.85 & 3.70 \\
\hline $\mathrm{K}_{2} \mathrm{O}$ & 1.46 & 1.32 & 1.67 & 1.61 & 1.75 & 1.75 & 1.75 & 1.75 & 1.52 & 1.83 & 1.33 & 1.39 & 1.67 & 1.31 & 1.35 & 1.54 \\
\hline $\mathrm{P}_{2} \mathrm{O}_{5}$ & 0.30 & 0.29 & 0.21 & 0.27 & 0.23 & 0.23 & 0.25 & 0.24 & 0.22 & 0.20 & 0.27 & 0.27 & 0.25 & 0.28 & 0.29 & 0.23 \\
\hline LOI & 0.26 & 0.33 & 0.42 & 0.23 & 0.34 & 0.44 & 0.34 & 0 & 0.04 & -0.29 & -0.09 & -0.06 & -0.17 & 0.35 & 0.33 & 0.23 \\
\hline Total & 100.9 & 98.71 & 99.65 & 98.2 & 99.37 & 99.04 & 100.7 & 100.5 & 99.09 & 100.1 & 100.4 & 98.67 & 99.9 & 100.3 & 101 & 99.71 \\
\hline $\mathrm{Sc}$ & 16.4 & 17 & 17.1 & 17.1 & 17.6 & 17.4 & 17.6 & 17.6 & 21.7 & 18 & 21.8 & 21.5 & 19.6 & 21.7 & 15.5 & 16.1 \\
\hline $\mathrm{V}$ & 142 & 144 & 136 & 131 & 128 & 128 & 129 & 130 & 145 & 129 & 155 & 151 & 137 & 149 & 143 & 143 \\
\hline $\mathrm{Cr}$ & 46.2 & 50.6 & 161 & 126 & 216 & 211 & 215 & 236 & 293 & 256 & 293 & 277 & 237 & 283 & 51.7 & 124 \\
\hline Co & 20.9 & 20.3 & 23.1 & 20.7 & 23.7 & 22.2 & 21.6 & 24.8 & 28.7 & 23.8 & 29.3 & 28.5 & 26.8 & 31.1 & 22.2 & 23.1 \\
\hline $\mathrm{Ni}$ & 39 & 41 & 80 & 74 & 101 & 103 & 107 & 102 & 112 & 102 & 126 & 121 & 111 & 128 & 44 & 75 \\
\hline $\mathrm{Cu}$ & 82 & 30 & 32 & 29 & 31 & 31 & 27 & 19 & 31 & 28 & 34 & 33 & 26 & 33 & 34 & 34 \\
\hline $\mathrm{Zn}$ & 78 & 75 & 62 & 67 & 61 & 63 & 61 & 59 & 55 & 54 & 62 & 62 & 59 & 62 & 76 & 68 \\
\hline $\mathrm{Rb}$ & 24 & 20 & 32 & 28 & 34 & 33 & 33 & 34 & 28 & 38 & 23 & 24 & 32 & 23 & 20 & 26 \\
\hline $\mathrm{Sr}$ & 513 & 500 & 378 & 422 & 396 & 377 & 385 & 389 & 397 & 371 & 424 & 422 & 395 & 421 & 497 & 414 \\
\hline $\mathrm{Y}$ & 18 & 18 & 16 & 18 & 17 & 18 & 18 & 17 & 17 & 17 & 19 & 18 & 19 & 19 & 19 & 19 \\
\hline $\mathrm{Zr}$ & 125 & 108 & 98 & 117 & 115 & 116 & 121 & 121 & 127 & 122 & 140 & 134 & 138 & 146 & 115 & 105 \\
\hline $\mathrm{Nb}$ & 7.8 & 7.4 & 7.2 & 8.8 & 8.8 & 8.5 & 9 & 9 & 8.4 & 7.9 & 8.7 & 9.2 & 9.3 & 9.7 & 5.7 & 6.3 \\
\hline Cs & 0.7 & 0.6 & 1 & 0.8 & 1 & 0.9 & 0.9 & 1 & 0.7 & 1.1 & 0.6 & 0.6 & 0.9 & 0.6 & 0.6 & 0.8 \\
\hline $\mathrm{Ba}$ & 458 & 417 & 439 & 447 & 456 & 454 & 452 & 459 & 415 & 471 & 403 & 397 & 455 & 405 & 418 & 422 \\
\hline $\mathrm{La}$ & 15.3 & 14.4 & 13.7 & 15.3 & 15.7 & 15.4 & 15.7 & 15.8 & 14.8 & 15.3 & 15 & 15.3 & 15.9 & 15.8 & 15.3 & 15.3 \\
\hline $\mathrm{Ce}$ & 31.4 & 29.8 & 27.7 & 31.1 & 31.6 & 31.6 & 31.7 & 31.9 & 30 & 30.7 & 31 & 31.2 & 31.9 & 32.4 & 31.9 & 30.8 \\
\hline $\operatorname{Pr}$ & 4.28 & 4.12 & 3.69 & 4.11 & 4.24 & 4.1 & 4.19 & 4.22 & 4.01 & 3.97 & 4.17 & 4.16 & 4.16 & 4.34 & 4.13 & 3.99 \\
\hline $\mathrm{Nd}$ & 18 & 17.1 & 14.6 & 16.3 & 17 & 16.3 & 17 & 16.8 & 16.3 & 15.9 & 16.9 & 17.4 & 16.4 & 17.5 & 17.5 & 16.7 \\
\hline $\mathrm{Sm}$ & 3.9 & 3.86 & 3.36 & 3.69 & 3.7 & 3.53 & 3.71 & 3.68 & 3.54 & 3.3 & 3.64 & 3.82 & 3.59 & 3.84 & 3.98 & 3.42 \\
\hline $\mathrm{Eu}$ & 1.31 & 1.26 & 1.02 & 1.12 & 1.15 & 1.12 & 1.14 & 1.1 & 1.08 & 0.987 & 1.2 & 1.18 & 1.13 & 1.22 & 1.16 & 1.04 \\
\hline $\mathrm{Gd}$ & 3.7 & 3.69 & 3.08 & 3.44 & 3.27 & 3.41 & 3.43 & 3.4 & 3.35 & 3.15 & 3.42 & 3.47 & 3.34 & 3.54 & 3.39 & 3.05 \\
\hline $\mathrm{Tb}$ & 0.58 & 0.57 & 0.5 & 0.53 & 0.53 & 0.54 & 0.55 & 0.56 & 0.56 & 0.53 & 0.55 & 0.58 & 0.55 & 0.58 & 0.54 & 0.51 \\
\hline Dy & 3.35 & 3.42 & 2.99 & 3.15 & 3.26 & 3.24 & 3.24 & 3.17 & 3.25 & 3.15 & 3.42 & 3.41 & 3.19 & 3.42 & 3.15 & 3.03 \\
\hline Ho & 0.67 & 0.68 & 0.61 & 0.64 & 0.67 & 0.64 & 0.65 & 0.63 & 0.63 & 0.6 & 0.71 & 0.69 & 0.66 & 0.68 & 0.63 & 0.61 \\
\hline Er & 1.9 & 1.88 & 1.78 & 1.83 & 1.85 & 1.82 & 1.86 & 1.84 & 1.79 & 1.73 & 1.94 & 1.94 & 1.98 & 1.92 & 1.81 & 1.75 \\
\hline $\mathrm{Tm}$ & 0.289 & 0.294 & 0.282 & 0.276 & 0.284 & 0.277 & 0.297 & 0.298 & 0.277 & 0.271 & 0.298 & 0.28 & 0.286 & 0.293 & 0.264 & 0.27 \\
\hline $\mathrm{Yb}$ & 1.92 & 1.88 & 1.87 & 1.82 & 1.94 & 1.78 & 1.87 & 1.84 & 1.87 & 1.78 & 1.92 & 1.9 & 1.89 & 2 & 1.7 & 1.67 \\
\hline $\mathrm{Lu}$ & 0.287 & 0.28 & 0.263 & 0.27 & 0.297 & 0.255 & 0.264 & 0.255 & 0.272 & 0.264 & 0.264 & 0.286 & 0.263 & 0.292 & 0.258 & 0.274 \\
\hline $\mathrm{Hf}$ & 2.6 & 2.7 & 2.6 & 2.9 & 3 & 2.8 & 3.1 & 3 & 3 & 2.7 & 2.8 & 2.9 & 2.9 & 3 & 2.6 & 2.3 \\
\hline $\mathrm{Ta}$ & 0.59 & 0.52 & 0.63 & 0.65 & 0.75 & 0.69 & 0.71 & 0.69 & 0.62 & 0.69 & 0.67 & 0.67 & 0.73 & 0.72 & 0.49 & 0.58 \\
\hline
\end{tabular}


stratification and hence have experienced minor amounts of disruption during transport, while lower hummocks that are made of looser, less-welded deposits underwent some disaggregation. The volume of all mappable hummocks makes $80 \mathrm{vol} \%$ of the breached sector, the rest probably consisting of smaller fragments (Table 1). It is hence likely that they are the product of the cone disruption late in the eruption, forming the breach that is still visible. Because the hummocks are not covered by other eruptive products, this disruption event apparently terminated the eruption.
Such features (hummocks made of piles of agglutinates over lavas) are common in basaltic lava fields and usually associated with cone breaching (e.g., Porter, 1972; Holm, 1987; Valentine et al., 2006; Németh et al., 2011; Kereszturi et al., 2012). A significant proportion of scoria cones in monogenetic fields is breached (global average: $32 \%$, TMVB average: $35 \%$, Tibaldi, 1995) and this breaching is often attributed to the effect of the intrusion of magma in the cone. Proximal exposures at Pinacate in NW Mexico show high amounts of magma injection (sills, dikes) and upwelling (lava lakes, overspills) within large cones,

Table 3. Bulk rock compositions (cont). Major elements (oxides) in wt. \%, trace elements in ppm.

\begin{tabular}{|c|c|c|c|c|c|c|c|c|c|c|c|c|c|c|c|c|}
\hline \multirow{2}{*}{$\begin{array}{l}\text { Sample } \\
\text { name }\end{array}$} & \multicolumn{16}{|c|}{ Tephra fallout $(2 / 3)$} \\
\hline & $295 \mathrm{~J}$ & $296 \mathrm{~J}$ & $1 \mathrm{~A}$ & $279 \mathrm{~A}$ & 279BD & 279BV & $279 \mathrm{C}$ & $279 \mathrm{D}$ & $279 \mathrm{E}$ & 279FD & $279 \mathrm{FV}$ & $279 \mathrm{H} 1$ & 27911 & $279 \mathrm{I} 2$ & $279 \mathrm{~J}$ & $279 \mathrm{~K}$ \\
\hline Lat N19 ${ }^{\circ}$ & $49^{\prime} 23.6 ”$ & $49^{\prime} 43.1 "$ & $49^{\prime} 58.9^{\prime \prime}$ & $49^{\prime} 47.0^{\prime \prime}$ & $49^{\prime} 47.0^{\prime \prime}$ & $49^{\prime} 47.0^{\prime \prime}$ & $49^{\prime} 47.0^{\prime \prime}$ & $49^{\prime} 47.0^{\prime \prime}$ & $49^{\prime} 47.0^{\prime \prime}$ & $49^{\prime} 47.0^{\prime \prime}$ & $49^{\prime} 47.0^{\prime \prime}$ & $49^{\prime} 47.0^{\prime \prime}$ & $49^{\prime} 47.0^{\prime \prime}$ & $49^{\prime} 47.0^{\prime \prime}$ & $49^{\prime} 47.0^{\prime \prime}$ & $49^{\prime} 47.0^{\prime \prime}$ \\
\hline Long W $101^{\circ}$ & $54 ' 29.2^{\prime \prime}$ & $55^{\prime} 39.6^{\prime \prime}$ & $53^{\prime} 26.8^{\prime \prime}$ & $53^{\prime} 51.7^{\prime \prime}$ & $53^{\prime} 51.7^{\prime \prime}$ & $53^{\prime} 51.7^{\prime \prime}$ & $53^{\prime} 51.7^{\prime \prime}$ & $53^{\prime} 51.7^{\prime \prime}$ & $53^{\prime} 51.7^{\prime \prime}$ & $53^{\prime} 51.7^{\prime \prime}$ & $53^{\prime} 51.7^{\prime \prime}$ & 53'51.7" & $53^{\prime} 51.7^{\prime \prime}$ & $53^{\prime} 51.7^{\prime \prime}$ & $53^{\prime} 51.7^{\prime \prime}$ & $53^{\prime} 51.7^{\prime \prime}$ \\
\hline Sample type & $\begin{array}{l}\text { bulk } \\
\text { scoria }\end{array}$ & $\begin{array}{l}\text { bulk } \\
\text { scoria }\end{array}$ & bomb & $\begin{array}{l}\text { bulk } \\
\text { scoria }\end{array}$ & $\begin{array}{l}\text { dense } \\
\text { scoria }\end{array}$ & $\begin{array}{c}\text { vesicular } \\
\text { scoria }\end{array}$ & $\begin{array}{c}\text { bulk } \\
\text { scoria }\end{array}$ & $\begin{array}{c}\text { bulk } \\
\text { scoria }\end{array}$ & $\begin{array}{c}\text { bulk } \\
\text { scoria }\end{array}$ & $\begin{array}{l}\text { dense } \\
\text { scoria }\end{array}$ & $\begin{array}{c}\text { vesicular } \\
\text { scoria }\end{array}$ & $\begin{array}{c}\text { bulk } \\
\text { scoria }\end{array}$ & $\begin{array}{c}\text { bulk } \\
\text { scoria }\end{array}$ & bomb & $\begin{array}{l}\text { vesicular } \\
\text { scoria }\end{array}$ & bomb \\
\hline $\mathrm{SiO} 2$ & 58.60 & 56.28 & 60.84 & 57.52 & 57.16 & 57.63 & 58.69 & 59.04 & 57.52 & 59.60 & 59.61 & 59.35 & 59.52 & 59.33 & 58.73 & 60.38 \\
\hline $\mathrm{TiO} 2$ & 0.85 & 0.76 & 0.63 & 0.93 & 0.91 & 0.88 & 0.85 & 0.86 & 0.85 & 0.86 & 0.86 & 0.83 & 0.87 & 0.87 & 0.80 & 0.74 \\
\hline $\mathrm{Al} 2 \mathrm{O} 3$ & 16.40 & 15.76 & 14.87 & 17.43 & 16.39 & 16.55 & 16.70 & 16.36 & 16.15 & 16.42 & 16.27 & 15.89 & 16.15 & 16.23 & 15.73 & 16.10 \\
\hline $\mathrm{Fe} 2 \mathrm{O} 3(\mathrm{~T})$ & 6.95 & 7.39 & 6.68 & 7.84 & 8.12 & 7.42 & 7.52 & 7.20 & 7.45 & 6.98 & 7.54 & 6.96 & 7.17 & 7.00 & 7.14 & 6.58 \\
\hline $\mathrm{MnO}$ & 0.12 & 0.12 & 0.15 & 0.13 & 0.21 & 0.13 & 0.13 & 0.13 & 0.13 & 0.12 & 0.13 & 0.12 & 0.13 & 0.12 & 0.13 & 0.12 \\
\hline $\mathrm{MgO}$ & 4.24 & 4.84 & 4.85 & 3.63 & 4.32 & 4.47 & 4.33 & 4.36 & 4.40 & 4.22 & 4.24 & 5.09 & 4.47 & 5.30 & 6.00 & 5.12 \\
\hline $\mathrm{CaO}$ & 6.16 & 6.41 & 5.77 & 6.40 & 6.84 & 6.38 & 6.29 & 6.31 & 6.26 & 5.94 & 5.88 & 6.14 & 6.15 & 6.37 & 6.90 & 6.24 \\
\hline $\mathrm{Na} 2 \mathrm{O}$ & 3.48 & 3.21 & 3.43 & 3.87 & 3.81 & 3.72 & 3.75 & 3.67 & 3.68 & 3.85 & 3.76 & 3.73 & 3.83 & 3.71 & 3.48 & 3.63 \\
\hline $\mathrm{K} 2 \mathrm{O}$ & 1.61 & 1.50 & 2.02 & 1.31 & 1.61 & 1.54 & 1.57 & 1.56 & 1.64 & 1.69 & 1.71 & 1.67 & 1.67 & 1.62 & 1.55 & 1.78 \\
\hline $\mathrm{P} 2 \mathrm{O} 5$ & 0.21 & 0.19 & 0.22 & 0.29 & 0.26 & 0.26 & 0.23 & 0.22 & 0.23 & 0.24 & 0.23 & 0.23 & 0.23 & 0.25 & 0.23 & 0.23 \\
\hline LOI & 0.6 & 2.91 & -0.13 & 0.67 & 1.2 & 0.55 & 0.88 & 0.71 & 0.77 & 0.68 & 0.72 & 0.2 & 0.46 & -0.05 & 0.11 & -0.3 \\
\hline Total & 99.22 & 99.37 & 99.31 & 100 & 100.8 & 99.52 & 101 & 100.4 & 99.09 & 100.6 & 100.9 & 100.2 & 100.7 & 100.8 & 100.8 & 100.6 \\
\hline $\mathrm{Sc}$ & 16.4 & 20 & 17.1 & 16.7 & 17.3 & 17.8 & 17.3 & 17.3 & 17.2 & 16.4 & 16 & 17.6 & 16.7 & 17.8 & 19.8 & 18.1 \\
\hline $\mathrm{V}$ & 139 & 119 & 105 & 145 & 138 & 142 & 143 & 140 & 139 & 128 & 126 & 128 & 132 & 134 & 138 & 125 \\
\hline $\mathrm{Cr}$ & 136 & 267 & 252 & 56.5 & 128 & 119 & 130 & 130 & 146 & 143 & 140 & 218 & 145 & 220 & 276 & 226 \\
\hline Co & 21.2 & 28.3 & 22.6 & 20.1 & 22.6 & 21.7 & 21.5 & 21.2 & 20.9 & 23.5 & 19.3 & 23.3 & 22.4 & 24.9 & 26.1 & 24.2 \\
\hline $\mathrm{Ni}$ & 68 & 91 & 103 & 37 & 63 & 61 & 60 & 63 & 65 & 67 & 67 & 87 & 69 & 94 & 107 & 92 \\
\hline $\mathrm{Cu}$ & 31 & 37 & 29 & 30 & 38 & 32 & 29 & 45 & 44 & 25 & 33 & 27 & 30 & 28 & 36 & 31 \\
\hline $\mathrm{Zn}$ & 66 & 57 & 133 & 82 & 102 & 69 & 71 & 79 & 70 & 66 & 66 & 59 & 70 & 59 & 60 & 55 \\
\hline $\mathrm{Rb}$ & 29 & 30 & 45 & 21 & 28 & 27 & 28 & 28 & 30 & 30 & 30 & 31 & 30 & 29 & 29 & 36 \\
\hline $\mathrm{Sr}$ & 414 & 360 & 381 & 493 & 459 & 435 & 435 & 411 & 407 & 430 & 422 & 401 & 447 & 413 & 374 & 368 \\
\hline $\mathrm{Y}$ & 20 & 17 & 24 & 17 & 24 & 19 & 17 & 18 & 18 & 18 & 17 & 18 & 18 & 17 & 17 & 16 \\
\hline $\mathrm{Zr}$ & 109 & 128 & 125 & 118 & 111 & 114 & 112 & 110 & 112 & 125 & 122 & 128 & 120 & 131 & 120 & 116 \\
\hline $\mathrm{Nb}$ & 6.2 & 7.2 & 46.9 & 7.4 & 9.2 & 8 & 8 & 6.9 & 7.5 & 7.5 & 7.4 & 7.2 & 7.3 & 6.8 & 6.6 & 6 \\
\hline Cs & 0.9 & 0.9 & 1.4 & 0.6 & 0.8 & 0.8 & 0.8 & 0.8 & 0.8 & 0.9 & 0.9 & 0.9 & 0.8 & 0.8 & 0.8 & 1 \\
\hline $\mathrm{Ba}$ & 450 & 421 & 1.4 & 430 & 584 & 453 & 472 & 428 & 455 & 463 & 466 & 447 & 469 & 447 & 423 & 467 \\
\hline $\mathrm{La}$ & 15.9 & 14.5 & 44.2 & 36 & 122 & 46.6 & 41.8 & 21.4 & 36.4 & 24.6 & 25 & 19.2 & 28 & 17 & 18.8 & 16 \\
\hline $\mathrm{Ce}$ & 31.7 & 28.9 & 90.2 & 61.3 & 251 & 83.2 & 78.8 & 39.5 & 68.8 & 46.6 & 47.2 & 36.9 & 55.6 & 33.5 & 36.7 & 31.9 \\
\hline $\operatorname{Pr}$ & 4.03 & 3.76 & 9.92 & 7.5 & 34.4 & 10.4 & 10.1 & 4.99 & 8.88 & 5.79 & 6.02 & 4.75 & 7.35 & 4.4 & 4.68 & 4.08 \\
\hline $\mathrm{Nd}$ & 16.2 & 15.9 & 32.2 & 29.4 & 144 & 39.6 & 39.7 & 20.2 & 36 & 23.3 & 23.4 & 18.8 & 30.5 & 18 & 18.7 & 16.3 \\
\hline $\mathrm{Sm}$ & 3.33 & 3.6 & 7.15 & 5.9 & 27.8 & 7.69 & 7.43 & 4.19 & 6.89 & 4.5 & 4.57 & 3.9 & 5.97 & 3.81 & 3.78 & 3.45 \\
\hline $\mathrm{Eu}$ & 1 & 0.952 & 2.27 & 1.72 & 6.4 & 2.15 & 1.97 & 1.28 & 1.84 & 1.33 & 1.34 & 1.16 & 1.59 & 1.09 & 1.07 & 0.95 \\
\hline $\mathrm{Gd}$ & 3.04 & 3.21 & 7.05 & 5.29 & 14.9 & 6 & 5.38 & 3.94 & 5.13 & 4.15 & 4.05 & 3.85 & 4.8 & 3.7 & 3.55 & 3.19 \\
\hline $\mathrm{Tb}$ & 0.51 & 0.53 & 1.03 & 0.75 & 1.31 & 0.81 & 0.72 & 0.64 & 0.68 & 0.65 & 0.64 & 0.61 & 0.67 & 0.6 & 0.57 & 0.52 \\
\hline Dy & 3 & 3.07 & 5.39 & 4.03 & 5.47 & 4.21 & 3.88 & 3.53 & 3.58 & 3.67 & 3.4 & 3.47 & 3.57 & 3.47 & 3.22 & 3.06 \\
\hline Ho & 0.58 & 0.6 & 0.96 & 0.75 & 0.93 & 0.74 & 0.7 & 0.68 & 0.7 & 0.69 & 0.66 & 0.67 & 0.67 & 0.66 & 0.64 & 0.62 \\
\hline Er & 1.71 & 1.69 & 2.6 & 2.02 & 2.53 & 2.14 & 1.98 & 1.93 & 1.97 & 1.93 & 1.87 & 1.95 & 1.95 & 1.91 & 1.87 & 1.77 \\
\hline $\mathrm{Tm}$ & 0.256 & 0.265 & 0.378 & 0.319 & 0.361 & 0.302 & 0.31 & 0.312 & 0.292 & 0.309 & 0.305 & 0.319 & 0.291 & 0.299 & 0.287 & 0.274 \\
\hline $\mathrm{Yb}$ & 1.65 & 1.75 & 2.41 & 2.01 & 2.35 & 2 & 1.97 & 1.95 & 1.97 & 1.94 & 2.06 & 1.99 & 1.87 & 1.94 & 1.83 & 1.79 \\
\hline $\mathrm{Lu}$ & 0.26 & 0.26 & 0.37 & 0.293 & 0.329 & 0.3 & 0.292 & 0.281 & 0.274 & 0.279 & 0.282 & 0.292 & 0.279 & 0.284 & 0.281 & 0.27 \\
\hline Hf & 2.6 & 2.7 & 3.5 & 2.8 & 2.8 & 2.7 & 2.7 & 2.8 & 2.7 & 3 & 2.9 & 3 & 3 & 3 & 2.8 & 2.7 \\
\hline $\mathrm{Ta}$ & 0.57 & 0.55 & 0.84 & 0.52 & 0.62 & 1.15 & 4.14 & 0.59 & 0.63 & 0.63 & 3.33 & 0.64 & 0.62 & 0.72 & 0.6 & 0.63 \\
\hline
\end{tabular}


which in most cases provoked catastrophic wall failure through the weakening of the cone base and outward pressure imparted on the wall (Gutmann, 1979). The hummocks are generally considered as having been carried away passively (rafted) on top of the lava that caused the breach in the first place (Gutmann, 1979; Holm, 1987; Valentine et al., 2006, 2007; Nemeth et al., 2011). Early studies suggest that this process mostly takes place near the end of the eruption (Scott and Trash, 1971; Gutmann, 1979), yet, later works show that it can occur at all stages of the eruption, as the cone breach can be sealed by subsequent explosions (Holm, 1987; Németh et al., 2011; Younger et al., 2019). At Paricutin, the main cone was breached numerous times during the early eruptive period, each of these events associated with rapid increases in lava outflow (Foshag and González-Reyna, 1956). Nevertheless, there are examples where the cone sector collapse seems to be unrelated to lava emissions (Tibaldi, 1995), such as the one described in detail at a historic, $180 \mathrm{~m}$-high cone in Tenerife (Romero et al., 2021). In this latter case, the processes involved and the resulting deposits closely resemble those associated with collapse at stratovolcanoes,

Table 3. Bulk rock compositions (final). Major elements (oxides) in wt. \%, trace elements in ppm.

\begin{tabular}{|c|c|c|c|c|c|c|c|c|c|c|c|c|c|c|c|c|}
\hline \multirow{2}{*}{$\begin{array}{l}\text { Sample } \\
\text { name }\end{array}$} & \multicolumn{5}{|c|}{ Tephra fallout $(3 / 3)$} & \multicolumn{3}{|c|}{ Xenolithic bombs } & \multicolumn{2}{|c|}{ Lava flow } & \multirow[b]{2}{*}{280} & \multirow[b]{2}{*}{282} & \multirow[b]{2}{*}{283} & \multirow[b]{2}{*}{$284 \mathrm{~B}$} & \multirow[b]{2}{*}{285} & \multirow[b]{2}{*}{293} \\
\hline & 2790 & $279 \mathrm{P}$ & $279 Q$ & $279 \mathrm{TD}$ & $279 \mathrm{TV}$ & $279 \mathrm{~N}$ & $194 \mathrm{~S}$ & $281 \mathrm{~A}$ & 8 & 21 & & & & & & \\
\hline Lat N19 & $49^{\prime} 47.0^{\prime \prime}$ & $49^{\prime} 47.0^{\prime \prime}$ & $49^{\prime} 47.0^{\prime \prime}$ & $49^{\prime} 47.0^{\prime \prime}$ & $49^{\prime} 47.0^{\prime \prime}$ & $49^{\prime} 47.0^{\prime \prime}$ & $50^{\prime} 00.2^{\prime \prime}$ & $49^{\prime} 23.2^{\prime \prime}$ & $50^{\prime} 38.8^{\prime \prime}$ & $50^{\prime} 35.7^{\prime \prime}$ & 49'36.9" & $49^{\prime} 25.8^{\prime \prime}$ & 49'38.8" & 49'25.9" & $49^{\prime} 11.00^{\prime \prime}$ & " 49'34.3" \\
\hline Long W $101^{\circ}$ & $53^{\prime} 51.7^{\prime \prime}$ & $53^{\prime} 51.7^{\prime \prime}$ & $53^{\prime} 51.7^{\prime \prime}$ & $53^{\prime} 51.7^{\prime \prime}$ & 53'51.7" & $53^{\prime} 51.7^{\prime \prime}$ & $53^{\prime} 10.5^{\prime \prime}$ & $51^{\prime} 31.3^{\prime \prime}$ & $50^{\prime} 54.8^{\prime \prime}$ & $50^{\prime} 53.5^{\prime \prime}$ & $51^{\prime} 09.5^{\prime \prime}$ & $51^{\prime} 58.5^{\prime \prime}$ & $53^{\prime} 52.0^{\prime \prime}$ & $52^{\prime} 29.7^{\prime \prime}$ & $51^{\prime} 0.54^{\prime \prime}$ & $49^{\prime} 53.0^{\prime \prime}$ \\
\hline Sample type & $\begin{array}{l}\text { bulk } \\
\text { scoria }\end{array}$ & bomb & $\begin{array}{l}\text { bulk } \\
\text { scoria }\end{array}$ & $\begin{array}{l}\text { dense } \\
\text { scoria }\end{array}$ & $\begin{array}{l}\text { vesicular } \\
\text { scoria }\end{array}$ & $\begin{array}{c}\text { bomb } \\
\text { with } \\
\text { xenolith }\end{array}$ & $\begin{array}{l}\text { light- } \\
\text { grey } \\
\text { bomb }\end{array}$ & $\begin{array}{l}\text { light- } \\
\text { grey } \\
\text { bomb }\end{array}$ & $\begin{array}{l}\text { lava } \\
\text { (late) }\end{array}$ & $\begin{array}{l}\text { lava } \\
\text { (late) }\end{array}$ & $\begin{array}{l}\text { lava } \\
\text { (late) }\end{array}$ & $\begin{array}{l}\text { lava } \\
\text { (hum- } \\
\text { mock) }\end{array}$ & $\begin{array}{l}\text { lava } \\
\text { (hum- } \\
\text { mock) }\end{array}$ & $\begin{array}{c}\text { lava } \\
\text { (agluti- } \\
\text { nate) }\end{array}$ & $\begin{array}{c}\text { lava } \\
\text { (early) }\end{array}$ & $\begin{array}{l}\text { lava } \\
\text { (late) }\end{array}$ \\
\hline $\mathrm{SiO} 2$ & 56.81 & 54.50 & 56.57 & 59.60 & 59.01 & 63.16 & 65.01 & 66.49 & 58.65 & 59.33 & 59.68 & 54.76 & 60.75 & 58.61 & 59.49 & 59.36 \\
\hline $\mathrm{TiO} 2$ & 0.90 & 0.97 & 1.01 & 0.77 & 0.81 & 0.65 & 0.60 & 0.47 & 0.75 & 0.87 & 0.85 & 0.92 & 0.81 & 0.94 & 0.88 & 0.78 \\
\hline $\mathrm{Al} 2 \mathrm{O} 3$ & 16.32 & 16.31 & 16.54 & 15.56 & 15.80 & 15.34 & 15.10 & 14.35 & 15.17 & 16.34 & 15.72 & 15.99 & 16.01 & 16.45 & 16.33 & 15.66 \\
\hline $\mathrm{Fe} 2 \mathrm{O} 3(\mathrm{~T})$ & 7.35 & 8.18 & 7.99 & 7.02 & 7.22 & 5.60 & 4.50 & 3.78 & 6.93 & 6.98 & 7.01 & 7.07 & 6.75 & 7.32 & 6.75 & 6.52 \\
\hline $\mathrm{MnO}$ & 0.13 & 0.14 & 0.13 & 0.12 & 0.12 & 0.11 & 0.10 & 0.08 & 0.12 & 0.13 & 0.12 & 0.12 & 0.12 & 0.12 & 0.12 & 0.12 \\
\hline $\mathrm{MgO}$ & 6.02 & 6.62 & 6.06 & 5.57 & 5.61 & 4.45 & 3.69 & 2.51 & 6.05 & 4.61 & 5.44 & 5.18 & 4.50 & 5.22 & 4.26 & 5.21 \\
\hline $\mathrm{CaO}$ & 7.14 & 7.48 & 7.18 & 6.59 & 6.66 & 4.79 & 4.62 & 3.70 & 6.85 & 6.32 & 6.36 & 6.65 & 6.04 & 6.74 & 6.02 & 6.14 \\
\hline $\mathrm{Na} 2 \mathrm{O}$ & 3.53 & 3.53 & 3.30 & 3.53 & 3.56 & 3.76 & 3.67 & 3.53 & 3.37 & 3.81 & 3.61 & 3.71 & 3.72 & 3.71 & 3.91 & 3.44 \\
\hline $\mathrm{K} 2 \mathrm{O}$ & 1.41 & 1.23 & 1.29 & 1.66 & 1.62 & 2.23 & 2.53 & 2.98 & 1.66 & 1.69 & 1.67 & 1.55 & 1.66 & 1.59 & 1.72 & 1.97 \\
\hline P2O5 & 0.25 & 0.29 & 0.27 & 0.21 & 0.23 & 0.16 & 0.17 & 0.11 & 0.23 & 0.27 & 0.24 & 0.27 & 0.21 & 0.28 & 0.24 & 0.21 \\
\hline LOI & 0.23 & -0.39 & 0.45 & 0.19 & 0.15 & 0.03 & 1.53 & 1.54 & 0.56 & -0.12 & 0.26 & 4.51 & -0.3 & -0.41 & -0.24 & 0.5 \\
\hline Total & 100.1 & 98.85 & 100.8 & 100.8 & 100.8 & 100.3 & 99.48 & 99.53 & 100.3 & 100.2 & 101 & 100.7 & 100.3 & 100.6 & 99.48 & 99.91 \\
\hline $\mathrm{Sc}$ & 20.3 & 21.7 & 21.3 & 17 & 19.9 & 14.5 & 12.5 & 10 & 19.8 & 17.6 & 18.1 & 19.1 & 16.4 & 19 & 16.4 & 17.9 \\
\hline $\mathrm{V}$ & 143 & 154 & 145 & 133 & 133 & 103 & 89 & 66 & 131 & 135 & 130 & 136 & 127 & 140 & 129 & 125 \\
\hline $\mathrm{Cr}$ & 235 & 294 & 231 & 221 & 248 & 178 & 165 & 100 & 277 & 182 & 222 & 178 & 173 & 175 & 126 & 276 \\
\hline Co & 26.8 & 32.2 & 28.2 & 20.6 & 26.2 & 20.1 & 18.1 & 13.5 & 22.9 & 23.7 & 24.4 & 24.6 & 23.2 & 25.3 & 21.1 & 24.8 \\
\hline $\mathrm{Ni}$ & 113 & 132 & 116 & 101 & 100 & 84 & 73 & 49 & 117 & 80 & 101 & 92 & 76 & 88 & 67 & 105 \\
\hline $\mathrm{Cu}$ & 39 & 41 & 48 & 28 & 53 & 29 & 15 & 14 & 25 & 29 & 30 & 56 & 34 & 32 & 26 & 27 \\
\hline $\mathrm{Zn}$ & 63 & 65 & 64 & 57 & 58 & 53 & 48 & 44 & 52 & 68 & 63 & 60 & 62 & 62 & 62 & 56 \\
\hline $\mathrm{Rb}$ & 26 & 21 & 23 & 31 & 30 & 48 & 53 & 61 & 29 & 31 & 30 & 29 & 30 & 30 & 31 & 37 \\
\hline $\mathrm{Sr}$ & 415 & 429 & 431 & 369 & 375 & 337 & 304 & 272 & 374 & 461 & 395 & 421 & 425 & 422 & 431 & 384 \\
\hline $\mathrm{Y}$ & 18 & 18 & 20 & 17 & 18 & 19 & 16 & 15 & 16 & 18 & 19 & 18 & 17 & 18 & 17 & 17 \\
\hline $\mathrm{Zr}$ & 131 & 131 & 142 & 122 & 122 & 120 & 119 & 108 & 119 & 130 & 131 & 124 & 117 & 140 & 119 & 114 \\
\hline $\mathrm{Nb}$ & 7.3 & 7 & 8.9 & 6.9 & 6.8 & 6.4 & 8.7 & 7 & 7.7 & 9.4 & 7.4 & 6.8 & 6.1 & 9 & 6.1 & 7.3 \\
\hline $\mathrm{Cs}$ & 0.6 & 0.5 & 0.5 & 0.8 & 0.8 & 1.4 & 1.6 & 2 & 0.8 & 1 & 0.8 & 0.7 & 0.9 & 0.8 & 0.9 & 0.9 \\
\hline $\mathrm{Ba}$ & 409 & 379 & 416 & 437 & 435 & 550 & 569 & 634 & 427 & 1 & 441 & 443 & 453 & 451 & 481 & 446 \\
\hline $\mathrm{La}$ & 16.5 & 16.2 & 17.6 & 18.2 & 18.6 & 16.3 & 16.6 & 18.4 & 15.4 & 24 & 17.4 & 18.8 & 16.3 & 17.4 & 16.7 & 16.6 \\
\hline $\mathrm{Ce}$ & 33.3 & 33.6 & 35.5 & 34.9 & 36.2 & 32.1 & 32.1 & 34.3 & 31.8 & 48 & 34.1 & 37.2 & 32.6 & 35.3 & 33.4 & 33.1 \\
\hline $\operatorname{Pr}$ & 4.44 & 4.52 & 4.79 & 4.5 & 4.7 & 4.02 & 3.99 & 4.07 & 3.83 & 5.6 & 4.44 & 4.91 & 4.29 & 4.69 & 4.43 & 4.28 \\
\hline $\mathrm{Nd}$ & 17.7 & 18.6 & 19.4 & 17.4 & 18.5 & 15.9 & 15.4 & 15.1 & 15.1 & 19.5 & 18.2 & 19.8 & 16.9 & 18.7 & 18.1 & 18.1 \\
\hline Sm & 3.77 & 3.94 & 4.13 & 3.75 & 3.84 & 3.26 & 3.12 & 3.04 & 3.29 & 4.14 & 3.69 & 4.2 & 3.71 & 3.84 & 3.85 & 3.62 \\
\hline $\mathrm{Eu}$ & 1.13 & 1.24 & 1.21 & 1.09 & 1.06 & 0.912 & 0.848 & 0.789 & 0.971 & 1.15 & 1.14 & 1.22 & 1.03 & 1.2 & 1.13 & 1.02 \\
\hline $\mathrm{Gd}$ & 3.75 & 4.02 & 4.01 & 3.49 & 3.53 & 2.74 & 2.87 & 2.56 & 3.3 & 3.6 & 3.56 & 4.01 & 3.57 & 3.85 & 3.72 & 3.19 \\
\hline $\mathrm{Tb}$ & 0.62 & 0.65 & 0.66 & 0.56 & 0.58 & 0.47 & 0.47 & 0.42 & 0.51 & 0.57 & 0.59 & 0.65 & 0.57 & 0.63 & 0.6 & 0.52 \\
\hline Dy & 3.48 & 3.6 & 3.73 & 3.32 & 3.32 & 2.85 & 2.81 & 2.51 & 3.06 & 3.31 & 3.39 & 3.73 & 3.28 & 3.65 & 3.48 & 3.11 \\
\hline Ho & 0.69 & 0.72 & 0.74 & 0.63 & 0.65 & 0.58 & 0.56 & 0.51 & 0.6 & 0.64 & 0.68 & 0.72 & 0.63 & 0.71 & 0.67 & 0.63 \\
\hline Er & 2.04 & 2.1 & 2.08 & 1.87 & 1.87 & 1.74 & 1.61 & 1.59 & 1.8 & 1.9 & 1.98 & 2.08 & 1.84 & 2.06 & 1.92 & 1.79 \\
\hline $\operatorname{Tm}$ & 0.312 & 0.331 & 0.327 & 0.295 & 0.298 & 0.265 & 0.252 & 0.25 & 0.274 & 0.293 & 0.301 & 0.321 & 0.286 & 0.317 & 0.292 & 0.268 \\
\hline $\mathrm{Yb}$ & 2.02 & 2.16 & 2.09 & 1.91 & 2 & 1.74 & 1.67 & 1.64 & 1.91 & 1.9 & 1.96 & 2.07 & 1.87 & 2.05 & 1.85 & 1.77 \\
\hline $\mathrm{Lu}$ & 0.292 & 0.299 & 0.318 & 0.299 & 0.297 & 0.279 & 0.252 & 0.253 & 0.293 & 0.301 & 0.305 & 0.303 & 0.28 & 0.312 & 0.297 & 0.275 \\
\hline Hf & 2.9 & 3 & 3.2 & 2.8 & 2.7 & 2.7 & 2.6 & 2.6 & 3.4 & 3.4 & 3 & 2.7 & 2.9 & 3.2 & 2.8 & 3 \\
\hline $\mathrm{Ta}$ & 0.61 & 0.71 & 0.64 & 0.61 & 0.6 & 0.41 & 0.85 & 0.89 & 0.75 & 0.25 & 0.64 & 0.72 & 0.73 & 0.73 & 0.63 & 0.65 \\
\hline
\end{tabular}



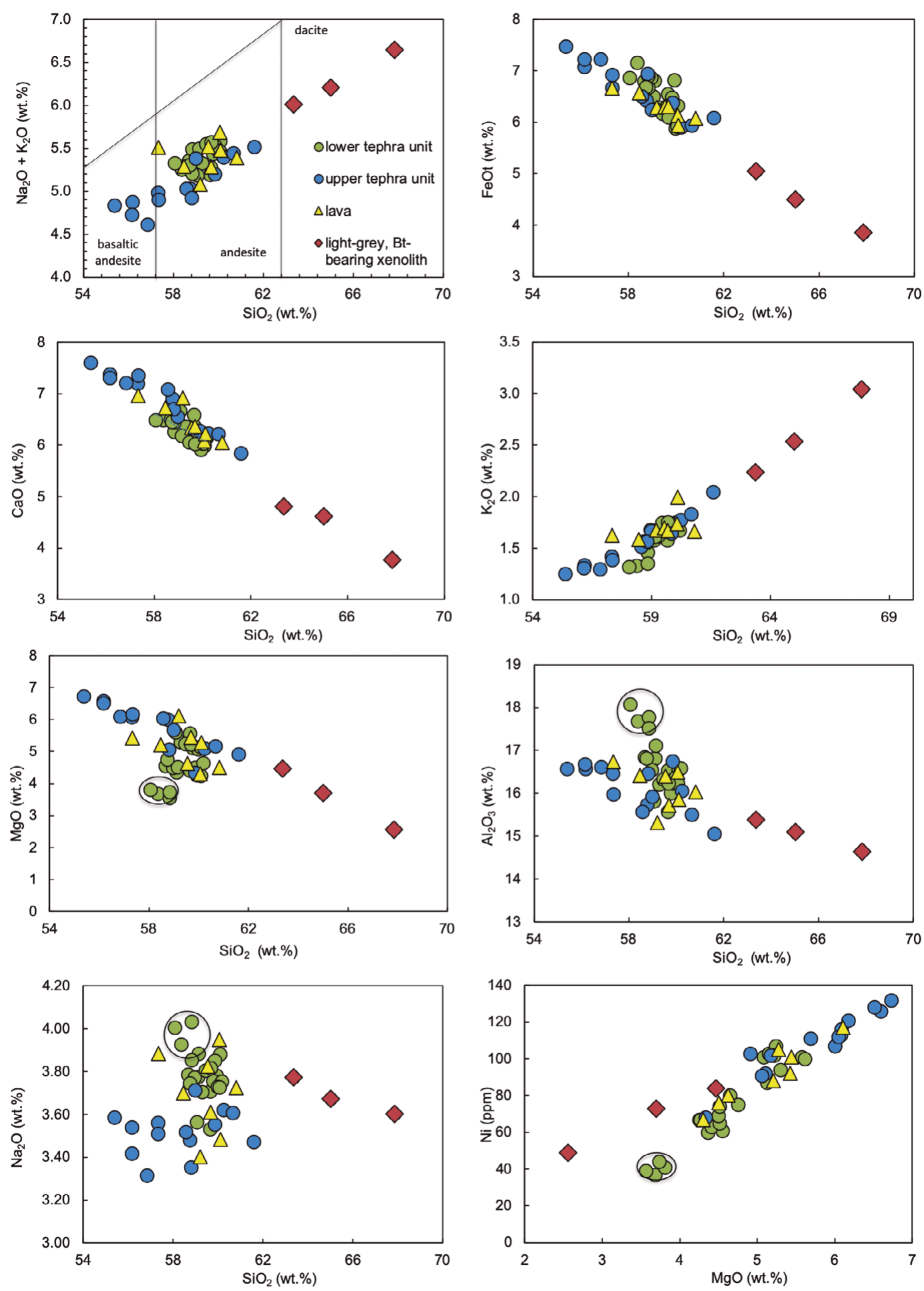

Figure 8. Major element compositions of Las Cabras samples. Note the straight linear trends followed by the samples with a higher content of light-grey xenolithic material (in red prisms). The circle locates samples from layers A and B that have slightly distinct compositions (see text). The lava samples (yellow triangles) show a broad affinity with the early tephra.

with faulting as a trigger, and ensuing violent explosive activity (Romero et al., 2021).

At Las Cabras, deep cuts into the lavas are largely absent and posteruptive weathering and anthropic activities (e.g., agriculture) have modified the surface hiding lithologic contacts. These circumstances prevented us from deciphering whether the hummocks are part of a debris avalanche deposit that was suddenly emplaced over the lavas or if they were transported by the lava itself in a more passive and slower rafting process. Nevertheless, the elongated shapes of many hummocks that are aligned in the main flow direction and their concentration in the late-formed open-channel suggest that they were emplaced along with the late lava outflow that formed the secondary lobes. Irrespective 
of the exact hummock transport mechanism, the intactness and large size of them indicate clearly that it was a catastrophic event and not the result of a long-lasting progressive, cone breaching process that would have resulted in higher fragmentation, such as observed elsewhere (Younger et al., 2019).

An analog for what could have happened at Las Cabras was found in the historical accounts of the Paricutin eruption (Foshag and GonzálezReyna, 1956). On June 20, 1943, a large collapse removed $1 / 4$ of the cone perimeter, the lava carrying "two long terraces" that originated as slumping blocks from the cone and contained pink oxidized material that crumbed down their steep slopes (note the resemblance with high hummocks at Las Cabras). Noteworthy, this event was preceded by "tremendous roar" followed by a "tremendous blast" that suggests the decompression of the magmatic system as a result of the cone failure. However, this event was followed at Paricutin by another eight years of activity whereas it was the last event at Las Cabras, possibly as a consequence of an end in the magma supply.

\section{Pre-existing slope and cone collapse}

Our study shows that the Las Cabras cone breaching was caused by the catastrophic destruction of its downslope-facing flank. All nearby cones also located on El Tule are equally breached in the direction of the shield's slopes (El Pueblito, El Molcajete, El Molcajetito, Figure 4 ), hence we believe that the inclined underlying slope was the main factor that promoted cone breaching. These other cones, however, do not preserve large hummocks such as those of Las Cabras, which may be partly related to their smaller size, or to posterior lava emissions covering them. El Tule shield flanks are relatively steep, ranging from 10 to 20 degrees in average. Such slope is high in comparison to the average of other shields measured in the MGVF and comparable to domes (Hasenaka, 1994), which probably reflect the andesitic composition of the shield and its poorly-altered morphology deriving from its young age (116 8 ka, Reyes Guzmán et al., 2018).

Analogue experiments of fluid intrusions within cones have been made to define the morphological parameters of scoria cones that inform about the geometry of their feeder dike (Tibaldi, 1995).
Those reveal that in case of a strong substrate inclination $\left(>9^{\circ}\right)$, the cone undergoes breaching in the downslope direction, irrespectively of other factors such as the strike or dip of the dike and cone and lava properties (density, height, etc.), showing that the effect of gravity dominates in such cases. Interestingly, sensors in the analogue cone detected a pressure increase in the downslope segment just prior to its collapse, which was related to the lateral loading effect of the dike-fed lava in that direction (Tibaldi, 1995). Thus, the relatively steep slope on which Las Cabras cone formed was a main conditioning factor for the collapse. As for the triggering, it is probable that the late intrusion of lava in the downslope cone segment would have weakened it and pushed it away, leading to sudden destabilization.

\section{Erosional processes and consequences for hazards}

Several of the structures preserved in the tephra deposits are indicative of the presence of considerable amounts of water in the environment during the explosive part of the eruption. The shallow channels that dissect packages of fine-grained layers in the lower part of the tephra sections can be compared to rills that cut into soils by the erosive action of flowing water. Tephra deposits are usually highly porous and do not present such behavior (water sips through quickly without eroding), but our granulometric data indicate that fine-grained layers at Las Cabras contain a high amount of very-fine-ash material that would have impeded infiltration and favored rill formation. In addition, the clear cuts observed at millimetric scale in the fine ash suggest the rapid formation above some layers of a superficial crust that acted as a water seal, maybe due to the impact of raindrops (Segerstrom, 1950). The formation of the rills was likely further promoted by the slope of the substrate, as observed at Paricutin (Segerstrom, 1950). The steepness of the channel walls evidences the high degree of cohesion of the compacted, water-soaked layers, and their preservation was possibly allowed by their rapid burying by subsequently-deposited tephra layers, indicating an uninterrupted tephra fall. The commonness of bomb impact sags can also be related to the wetness of the tephra layers (in particular the fine-grained ones) that deformed both plastically and brittlely upon impact.
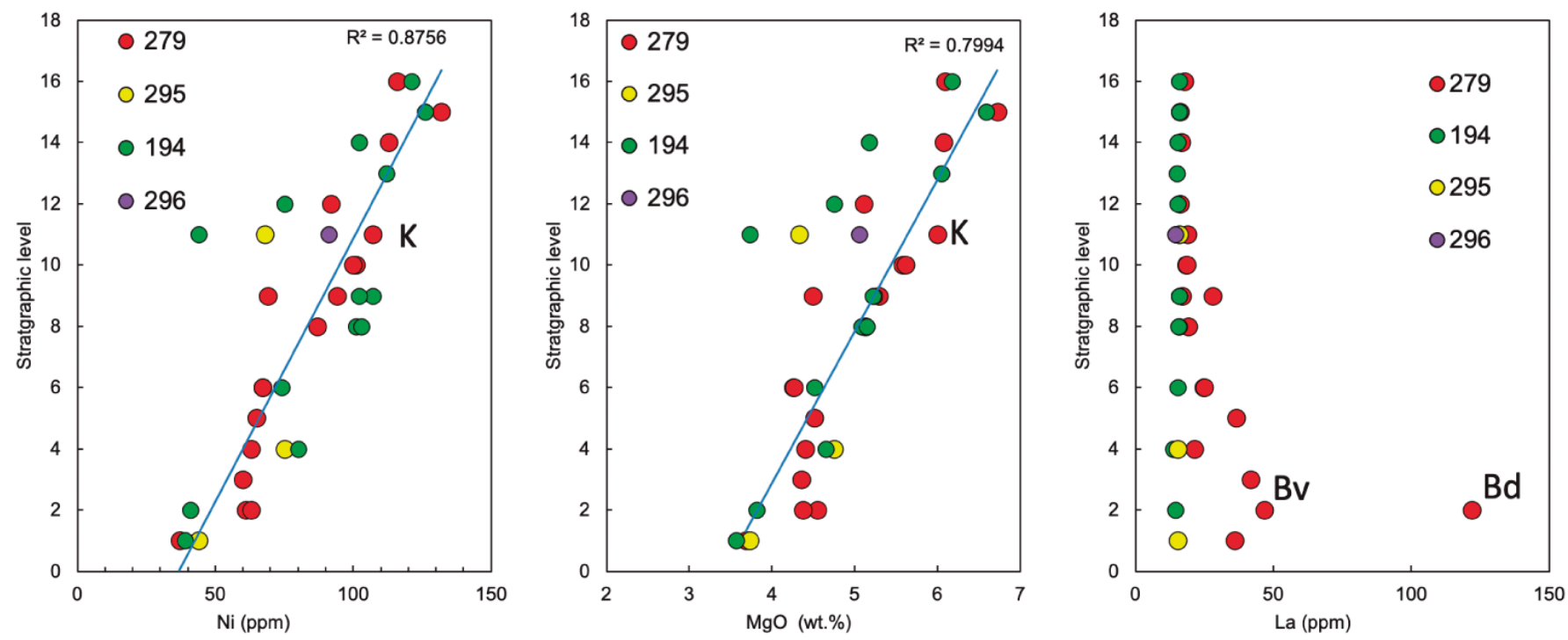

Figure 9. Stratigraphic variations of $\mathrm{Ni}, \mathrm{MgO}$, and $\mathrm{La}$ in tephra marker beds. Note the broad linear trend for $\mathrm{Ni}$ and $\mathrm{MgO}$, despite some scatter between different sections, in particular for layer $\mathrm{K}$ (the blue line shows the linear least-square fit of data from section 279 , and the value of the residual squared $\mathrm{R}_{2} \mathrm{is}$ reported). For $\mathrm{La}$, note that only samples from the lower unit of section 279 (Figures 4 and 6) are enriched in this element. Dense oxidized clasts of layer B (Bd on figure) have the highest concentrations, whereas vesicular clasts from the same layer (Bv on figure) are less enriched. This behavior was observed for all light REE. 
In regard to the origin of the water, an underground or superficial source (such as a river, small pond, or a shallow aquifer) seems unlikely as the strata lack the peculiarities of phreatomagmatic deposits that typically display pervasive cross-bedding, high xenolith content, poorly-vesicular juveniles, cauliflower textures, and accretionary lapilli in fine layers (e.g., Kshirsagar et al., 2015). Instead, its origin might be sought in torrential rain, hence indicating wet paleoclimatic conditions. Would this be consistent with independent paleoclimatic data? The revision of paleosol dates suggests that the eruption occurred at 26-27 kyrs BP, which corresponds to the beginning of the last glacial maximum (26.5-19 kyrs BP; Clark et al., 2009). Despite some inconsistencies in paleoclimatic evidence from lakes in Central Mexico (Kshirsagar et al., 2015), it seems that this was a cold and wet period in this area, coherent with our interpretations. Note however that similar erosive processes occurred during the Paricutin eruption (Segerstrom, 1950), indicating that it can occur in modern days in this region.

Such intense rain-driven tephra erosion has consequences for hazards, as observed during numerous historic eruptions, including Paricutin (Segerstrom, 1950) and Jorullo (Guilbaud et al., 2009). During the Las Cabras eruption, this would have produced in the early stages lahars or debris flows that would have affected the valley between the El Tule and Tecolote shields, maybe even reaching the Zacapu lake shore located $9 \mathrm{~km}$ downslope. For example, at Jorullo, eruption-related lahar deposits were found in the village of La Huacana located $10 \mathrm{~km}$ downslope from the vent (Guilbaud et al., 2009), proving that lahars generated during monogenetic eruptions can reach long distances. Related deposits would have been mostly covered by the lavas emitted later and which flowed in the same direction.

\section{Magmatic processes}

Juvenile products from the Las Cabras eruption spread a notable range in bulk composition ( $8 \mathrm{wt} \%$ in $\mathrm{SiO}_{2}, 4 \mathrm{wt} \%$ in $\mathrm{MgO}$ ) and present textural characteristics that suggest processes of magma contamination, mixing, and differentiation. Our observations allow some preliminary insights into those processes and place constraints on future models that should include isotopic data.

The linear trends observed in bimodal plots could be either explained by a process of fractional crystallization of the observed mineral phases $(\mathrm{Pl}, \mathrm{Ol}, \mathrm{Px}, \mathrm{Ox})$, or by a process of assimilation of the dacitic magma which was found as xenoliths in the late tephra. Nevertheless, the mingling textures, absence of dacitic minerals such as Bt in the juvenile andesite, as well as the similar range in bulk composition of early and late tephra, indicate limited mixing and assimilation of this dacitic melt, which is hence unlikely to have caused the compositional trends. Nonetheless, all phenocrysts in the juveniles display textures that indicate that they were at disequilibrium with their host. Therefore, their presence points to mixing of the main andesitic magma with other melts of different origins or storage conditions, which should be constrained by more detailed petrographic work and compositional data (mineral compositions, isotopic ratios). As other volcanoes in this area present similar textural characteristics (e.g., Reyes-Guzmán et al., 2018), we hypothesize that this process could be common in the area, and responsible for the dominance of andesites.

There is a broad increase in bulk $\mathrm{MgO}$ and $\mathrm{Ni}$ with stratigraphic height in the tephra that could have two causes. The emitted melts could have become increasingly more primitive during the eruption, due to a continuous replenishment of the shallow system by more primitive magmas from depth (magma recharge). Alternatively, a process of physical separation of the crystals in the shallow magma reservoir or in the conduit could have progressively increased the concentrations in $\mathrm{Ol}$ in the erupted melt and decreased those of $\mathrm{Pl}$, due to their density contrast. Our modal analysis does not show a significant and clear trend of Ol-enrichment in the section, which tend to favor the first hypothesis (magma recharge), while the higher content in $\mathrm{Ol}$ in the upper tephra (Table 2) can be related to their higher proportions in these more primitive melts.

The occurrence of large dacitic bombs with quenched margins in the late tephra indicate that at that stage of the eruption, the andesitic melt intersected a hot, dacitic magma batch that was probably residing at shallow depth below the vent. The appearance of the dacitic xenoliths coincides with a marked decrease in eruption explosivity (increase in bomb sizes and abundance) that finally led to lava emission. A widening (or flaring) in the vent could both explain a decrease in flux and hence explosive intensity, as well as the intersection of an adjacent dacitic magma body. The origin of this dacitic melt is uncertain. However, we note that it could possibly be derived from the andesitic magma by crystal fractionation of $\mathrm{Hbl}, \mathrm{Opx}$, or Bt, considering their similar trace element patterns. A non-cogenetic origin (a distinct dike and mantle source) is also possible as evolved magmas have erupted at different locations in the area during this time period (Reyes-Guzmán et al., 2018).

\section{CONCLUSIONS}

Our study of Las Cabras volcano allows to reconstruct its eruption. It occurred sometime between 27 to $26 \mathrm{kyrs}$ BP and represents a relatively large eruption (Volcanic Explosivity Index = 1-2; Newhall and Self, 1982), whose style evolved from Strombolian to effusive. Early explosive activity built a large cone which experienced a sector collapse at the end of the eruption. The collapse was likely triggered by lava intrusion in the cone that became gravitationally unstable due to the steep underlying slopes. The event was catastrophic, removing a quarter of the original cone and leaving a trail of large, elongated hummocks on the lava. The lava flow was emplaced in a valley between prominent volcanic shields, reaching long distances $(>7 \mathrm{~km})$. Heavy rain during the eruption caused syn-eruptive erosion of the early tephra, due to its fine-ash nature and the slope on which it was deposited. This erosion probably generated lahars, which followed the valley and might have reached the Zacapu lake shore. Complex processes occurred in the magma conduit and feeding system, involving mixing and mingling between distinct magma batches.

This study has several implications for our knowledge of the factors controlling cone-forming monogenetic volcanoes. It shows that the formation of such a volcano on a terrain with a marked slope $(>10$ degrees) has strong impacts on the stability of the volcanic edifice and the geometry of the resulting lava field. It also evidences the erosive effect of intense rain on fine-grained tephra fallout strata deposited on slope, which may have generated hazardous lahars. Finally, it reveals the complex mixing and mingling processes that may occur in the shallow magmatic plumbing system of monogenetic volcanoes, specifically in inland areas of continental arcs. In such areas, the crust may hold abundant stalled, cooling melts that are intersected and partly mix with new injections of primitive mantle melts that occasionally reach the surface.

\section{ACKNOWLEDGEMENTS}

Several team members (former and present) assisted during field work, including Pooja Kshirsagar, Gustavo Vivó Vásquez, Oryaelle Chevrel, Balam Molina de Artola, Juan Ramón de la Fuente and Nanci Reyes-Guzmán. We thank Américo González-Esparza, Adriana Briseño, and Ernesto Andrade at UNAM Campus Morelia for providing lodging facilities at the Mexican Array Radio Telescope near Coeneo 
during field campaigns. Capitán Fernando Valencia is thanked for skillful and safe flights over the study area. Reviewers Karoly Németh and Dario Pedrazzi and journal editors Isabel Israde Alcántara and José Luis Macías were very helpful and we are thankful for their valuable suggestions. The project was supported by UNAM-funded projects DGAPA-PAPIIT-IN103421 to MNG and IN104221 to CS. AHJ received a scholarship from project 152294 funded by CONACYT.

\section{REFERENCES}

Agustín-Flores, J., Siebe, C., Guilbaud, M.N., 2011, Geology and geochemistry of Pelagatos, Cerro del Agua, and Dos Cerros monogenetic volcanoes in the Sierra Chichinautzin volcanic field, south of Mexico City: Journal of Volcanology and Geothermal Research, 201(1-4), 143-162, https://doi. org/10.1016/j.jvolgeores.2010.08.010

Albert, H., Costa, F., Martí, J., 2016, Years to weeks of seismic unrest and magmatic intrusions precede monogenetic eruptions: Geology, 44(3), 211-214.

Albert, H., Larrea, P., Costa, F., Widom, E., Siebe, C., 2020, Crystals reveal magma convection and melt transport in dyke-fed eruptions: Scientific Reports, 10(1), 1-10, https://doi.org/10.1038/s41598-020-68421-4

Arnauld, M.C., Faugère-Kalfon, B., 1998, Evolución de la ocupación humana en el centro-norte de Michoacán (Proyecto Michoacán, CEMCA) y la emergencia del Estado Tarasco. in Darras, V. (ed.), Génesis, culturas y espacios en Michoacán: Ciudad de México, México. Centro de Estudios Mexicanos y Centroamericanos. México, 13-34.

Ban, M., Hasenaka, T., Delgado Granados, H., Takaoka, N., 1992, K-Ar ages of lavas from shield volcanoes in the Michoacán-Guanajuato volcanic field, Mexico: Geofísica Internacional, 31, 467-473.

Becerril, L., Larrea, P., Salinas, S., Mossoux, S., Ferrés, D., Widom, E., Siebe, C., Martí, J., 2021, The historical case of Paricutin volcano (Michoacán, México): challenges of simulating lava flows on a gentle slope during a long-lasting eruption: Natural Hazards, 107, 1-21, https://doi.org/10.1007/ s11069-021-04607-x

Blatter, D.L., Hammersley, L., 2010, Impact of the Orozco Fracture Zone on the central Mexican Volcanic Belt: Journal of Volcanology and Geothermal Research, 19781-4), 67-84.

Clark, P.U., Dyke, A.S., Shakun, J.D., Carlson, A.E., Clark, J., Wohlfarth, B., Mitrovica, J.X., Hostetler, S.W., McCabe, A. M., 2009, The last glacial maximum: Science, 325(5941), 710-714.

Chevrel, M.O., Siebe, C., Guilbaud, M.N., Salinas, S., 2016, The AD 1250 El Metate shield (Michoacán): Mexicoss most voluminous Holocene eruption and its significance for archaeology and hazards: The Holocene, 26(3), 471-488, https://doi.org/10.1177/0959683615609757

Connor, C.B., 1990, Cinder cone clustering in the Trans-Mexican Volcanic Belt: implications for structural and petrologic models: Journal of Geophysical Research Solid Earth, 95(B12), 19395-19405.

Darras, V., Mireles, C., Siebe, C., Quezada, O., Castañeda, A., ReyesGuzmán, N., 2017, The other stone: Dacite quarries and workshops in the Tarascan prehispanic territory, Michoacán, México: Journal of Archaeological Science Reports, 12(4), 219-231, https://doi.org/10.1016/j. jasrep.2017.01.034

Di Traglia, F., Cimarelli, C., De Rita, D., Torrente, D.G., 2009, Changing eruptive styles in basaltic explosive volcanism: Examples from Croscat complex scoria cone, Garrotxa Volcanic Field (NE Iberian Peninsula): Journal of Volcanology and Geothermal Research, 180(2-4), 89-109.

Dóniz-Páez, J., 2015, Volcanic geomorphological classification of the cinder cones of Tenerife (Canary Islands, Spain): Geomorphology, 228, 432-447.

Folk, R.L., 1974, Petrology of sedimentary rocks: Austin, Texas, Hemphill, $182 \mathrm{pp}$.

Forest, M. Jadot, E., Testard, J., 2019, Mazapan-style figurines at El Palacio and their Significance for Early Postclassic regional interactions in Northern Michoacan. Ancient Mesoamerica: Cambridge University Press, 1-20. $10.1017 /$ S0956536119000026

Foshag, W.F., González-Reyna, J.R., 1956, Birth and development of Paricutin volcano, Mexico: United States Geological Survey Bulletin D, 965, 355-489.

Gardine, M., West, M.E., Cox, T., 2011, Dike emplacement near Parícutin volcano, Mexico in 2006: Bulletin of Volcanology, 73(2), 123-132.
Gómez-Vasconcelos, M.G., Avellán, D.R., Soria-Caballero, D., Macías, J.L., Velázquez-Bucio, M.M., Jiménez-Haro, A., Israde-Alcántara, I., GarduñoMonroy, V.H., Ávila-Olivera, J.A., Figueroa-Soto, A., Cisneros-Máximo, G., Cardona-Melchor, S., 2021, Geomorphic characterization of faults as earthquake sources in the Cuitzeo Lake basin, central México: Journal of South American Earth Sciences, 103196, https//doi.org/10-1016/j. jsames.2021.103196

Guilbaud, M.N., Self, S., Thordarson, T., Blake, S., 2005, Morphology, surface structures, and emplacement of lavas produced by Laki, AD 1783-1784: Geological Society of America Special Papers, 396, 81-102.

Guilbaud, M.-N., Siebe, C., Salinas, S., 2009, Excursions to Paricutin and Jorullo (Michoacán), the youngest volcanoes of the Trans-Mexican Volcanic Belt: Impretei, México D.F., 31 pp.

Guilbaud, M.-N., Siebe, C., Layer, P., Salinas, S., Castro-Govea, R., GarduñoMonroy, V.H., Le Corvec, N., 2011, Geology, geochronology, and tectonic setting of the Jorullo volcano region, Michoacán, México: Journal of Volcanology and Geothermal Research, 201, 97-112, https://doi. org/10.1016/j.jvolgeores.2010.09.005

Guilbaud, M.-N., Siebe, C., Layer, P., Salinas, S., 2012, Reconstruction of the volcanic history of the Tacámbaro-Puruarán area (Michoacán, México) reveals high frequency of Holocene monogenetic eruptions: Bulletin of Volcanology, 74, 1187-1211, https://doi.org/10.1007/s00445-012-0594-0

Guilbaud, M.-N., Siebe, C., Rasoazanamparany, C., Widom, E., Salinas, S., Castro Govea, R., 2019, Petrographic, Geochemical and Isotopic (Sr-Nd$\mathrm{Pb}-\mathrm{Os}$ ) Study of Plio-Quaternary Volcanics and the Tertiary Basement in the Jorullo-Tacámbaro Area, Michoacán-Guanajuato Volcanic Field, Mexico: Journal of Petrology, 60(12), 2317-2338, https://doi.org/10.1093/ petrology/egaa006

Gutmann, J.T., 1979, Structure and eruptive cycle of cinder cones in the Pinacate volcanic field and the controls of Strombolian activity: The Journal of Geology, 87(4), 448-454.

Hasenaka, T., Carmichael, I.S.E., 1985, The cinder cones of MichoacánGuanajuato, central Mexico: their age, volume and distribution, and magma discharge rate: Journal of Volcanology and Geothermal Research, $25,105-124$.

Hasenaka, T., 1994, Size, distribution, and magma output rate for shield volcanoes of the Michoacán-Guanajuato volcanic field, Central Mexico: Journal of Volcanology and Geothermal Research, 63(1-2), 13-31.

Hasenaka, T., Carmichael, I.S.E., 1987, The cinder cones of MichoacánGuanajuato, central Mexico: Petrology and chemistry: Journal of Petrology, $28,241-269$.

Hernández Jiménez, A., 2016, El Volcán Las Cabras, Cuenca de Zacapu, Michoacán, México: Edad, historia eruptiva y composicion química: Mexico City, Facultad de Ciencias, Universidad Nacional Autónoma de Mexico, Undergraduate thesis, $92 \mathrm{pp}$.

Holm, R.F., 1987, Significance of agglutinate mounds on lava flows associated with monogenetic cones: An example at Sunset Crater, northern Arizona: Geological Society of America Bulletin, 99(3), 319-324.

Hopkins, J.L., Smid, E.R., Eccles, J.D., Hayes, J.L., Hayward, B.W., McGee, L.E., van Wijk, K., Wilson, T.M., Cronin, S.J., Leonard, G.S., Lindsay, J.M., Németh, K., Smith, I.E., 2020, Auckland Volcanic Field magmatism, volcanism, and hazard: a review: New Zealand Journal of Geology and Geophysics, 1-22, DOI:10.1080/00288306.2020.1736102

Houghton, B.F., Bonadonna, C., Gregg, C.E., Johnston, D.M., Cousins, W.J., Cole, J.W., Del Carlo, P., 2006, Proximal tephra hazards: Recent eruption studies applied to volcanic risk in the Auckland volcanic field, New Zealand: Journal of Volcanology and Geothermal Research, 155(1-2), 138-149.

INEGI (Instituto Nacional de Estadística, Geografía e Informática), 2016, Modelos digitales de elevación tipo terreno con $5 \mathrm{~m}$ de resolución, E14A11D1; E14A11D2; E14A11D3; E14A11D4; E14A11E1; E14A11E2; E14A11E3; E14A11E4; E14A11F1 y E14A11F3, escala 1:10,000: México.

INEGI (Instituto Nacional de Estadística, Geografía e Informática), 2020, Censo de Población y Vivienda 2020: Ciudad de México, México.

Jankovics, M.É., Sági, T., Astbury, R.L., Petrelli, M., Kiss, B., Ubide, T., Németh, K., Ntaflos, T., Harangi, S., 2019, Olivine major and trace element compositions coupled with spinel chemistry to unravel the magmatic systems feeding monogenetic basaltic volcanoes: Journal of Volcanology and Geothermal Research, 369, 203-223.

Johnson, E.R., Wallace, P.J., Cashman, K.V., Granados, H.D., Kent, A.J., 2008, Magmatic volatile contents and degassing-induced crystallization at 
Volcán Jorullo, Mexico: Implications for melt evolution and the plumbing systems of monogenetic volcanoes: Earth and Planetary Science Letters, 269(3-4), 478-487.

Johnson, E.R., Wallace, P.J., Cashman, K.V., Granados, H.D., 2010, Degassing of volatiles $\left(\mathrm{H}_{2} \mathrm{O}, \mathrm{CO}_{2}, \mathrm{~S}, \mathrm{Cl}\right)$ during ascent, crystallization, and eruption at mafic monogenetic volcanoes in central Mexico: Journal of Volcanology and Geothermal Research, 197(1-4), 225-238.

Kereszturi, G., Jordan, G., Németh, K., Dóniz-Páez, J.F., 2012, Syn-eruptive morphometric variability of monogenetic scoria cones: Bulletin of Volcanology, 74(9), 2171-2185.

Krauskopf, K.B., 1948, Mechanism of eruption at Paricutin volcano, Mexico: Geological Society of America Bulletin, 59(8), 711-732.

Kshirsagar, P., Siebe, C., Guilbaud, M.N., Salinas, S., Layer, P.W., 2015, Late Pleistocene Alberca de Guadalupe maar volcano (Zacapu basin, Michoacán): Stratigraphy, tectonic setting, and paleo-hydrogeological environment: Journal of Volcanology and Geothermal Research, 304, 214-236, https://doi.org/10.1016/j.jvolgeores.2015.09.003

Kshirsagar, P., Siebe, C., Guilbaud, M.N., Salinas, S., 2016, Geological and environmental controls on the change of eruptive style (phreatomagmatic to Strombolian-effusive) of Late Pleistocene El Caracol tuff cone and its comparison with adjacent volcanoes around the Zacapu basin (Michoacán, México): Journal of Volcanology and Geothermal Research, 318, 114-133, https://doi.org/10.1016/j.jvolgeores.2016.03.015

Larrea, P., Salinas, S., Widom, E., Siebe, C., Abbitt, R.J., 2017, Compositional and volumetric development of a monogenetic lava flow field: The historical case of Paricutin (Michoacán, Mexico): Journal of Volcanology and Geothermal Research, 348, 36-48, https://doi.org/10.1016/j. jvolgeores.2017.10.016

Larrea, P., Widom, E., Siebe, C. Salinas, S., Kuentz, D., 2019a, A re-interpretation of the petrogenesis of Paricutin volcano: Distinguishing crustal contamination from mantle heterogeneity: Chemical Geology, 504, 6682, https://doi.org/10.1016/j.chemgeo.2018.10.026

Larrea, P., Siebe, C., Juárez-Arriaga, E., Salinas, S., Ibarra, H., Böhnel, H., 2019b, The $\sim$ AD 500-700 (Late Classic) El Astillero and El Pedregal volcanoes (Michoacán, Mexico): a new monogenetic cluster in the making?: Bulletin of Volcanology, 81(10), 59, https://doi.org/10.1007/s00445-019-1318-5

Larrea, P., Albert, H., Ubide, T., Costa, F., Colás, V., Widom, E., Siebe, C., 2021, From explosive vent opening to effusive outpouring: mineral constraints on magma dynamics and timescales at Paricutin monogenetic volcano: Journal of Petrology, egaa112, https://doi.org/10.1093/petrology/egaa112

Lorenzo-Merino, A., Guilbaud, M.N., Roberge, J., 2018, The violent Strombolian eruption of 10 ka Pelado shield volcano, Sierra Chichinautzin, Central Mexico: Bulletin of Volcanology, 80(3), 1-17.

Losantos, E., Cebriá, J.M., Morán-Zenteno, D.J., Martiny, B.M., López-Ruiz, J., Solís-Pichardo, G., 2017, Petrogenesis of the alkaline and calcalkaline monogenetic volcanism in the northern sector of the MichoacánGuanajuato Volcanic Field (Central Mexico): Lithos, 288, 295-310.

Luhr, J.F., Carmichael, I.S.E., 1985, Jorullo Volcano, Michoacán, Mexico (1759-1774): the earliest stages of fractionation in calc-alkaline magmas: Contributions to Mineralogy and Petrology, 90, 142-161.

Luhr, J.F., Simkin, T., 1993, Parícutin: the volcano born in a Mexican cornfield: Phoenix, Arizona, Geoscience Press, 427 pp.

Macías, J.L., Arce, J.L., 2019, Volcanic activity in Mexico during the Holocene, in The Holocene and Anthropocene Environmental History of Mexico: Switzerland, Springer Verlag, 129-170.

Mahgoub, A.N., Böhnel, H., Siebe, C., Salinas, S., Guilbaud, M.N., 2017, Paleomagnetically inferred ages of a cluster of Holocene monogenetic eruptions in the Tacámbaro-Puruarán area (Michoacán, Mexico): Implications for future hazards: Journal of Volcanology and Geothermal Research, 347, 360-370, https://doi.org/10.1016/j.jvolgeores.2017.10.004

Mahgoub, A.N., Reyes-Guzmán, N., Böhnel, H., Siebe, C., Pereira, G., Dorison, A., 2018, Paleomagnetic constraints on the ages of the Holocene Malpaís de Zacapu lava flow eruptions, Michoacán (Mexico): implications for archeology and volcanic hazards: The Holocene, 28(2), 229-245, https:// doi.org/10.1177/0959683617721323

Martin, U., Németh, K., 2006, How Strombolian is a "Strombolian" scoria cone? Some irregularities in scoria cone architecture from the Transmexican Volcanic Belt, near Volcán Ceboruco (Mexico) and Al Haruj (Libya): Journal of Volcanology and Geothermal Research, 155(1-2), 104-118.
Mannen, K., Ito, T., 2007, Formation of scoria cone during explosive eruption at Izu-Oshima volcano, Japan: Geophysical Research Letters, 34(18), 1-5.

McBirney, A.R., Taylor, H.P., Armstrong, R.L., 1987, Paricutin re-examined: a classic example of crustal assimilation in calc-alkaline magma: Contributions to Mineralogy and Petrology, 95(1), 4-20.

Michelet, D., Arnauld, M.C., Fauvet-Berthelot, M.F., 1989, El Proyecto del CEMCA en Michoacán. Etapa I. Un balance: TRACE, 16, 70-87.

Migeon, G., 1998, El poblamiento del Malpaís de Zacapu y de sus alrededores del Clásico al Posclásico, in Darras, V. (ed.) Génesis, culturas y espacios en Michoacán: México, Centro de estudios mexicanos y centroamericanos (CEMCA), 36-45, https://doi.org/10.4000/books.cemca.3395.

Murcia, H., Németh, K., El-Masry, N.N., Lindsay, J.M., Moufti, M.R.H., Wameyo, P., Cronin, S.J., Smith, I.E.M, Kereszturi, G., 2015, The Al-Du'aythah volcanic cones, Al-Madinah City: implications for volcanic hazards in northern Harrat Rahat, Kingdom of Saudi Arabia: Bulletin of Volcanology, 77(6), 54, 1-19.

Németh, K., Risso, C., Nullo, F., Kereszturi, G., 2011, The role of collapsing and cone rafting on eruption style changes and final cone morphology: Los Morados scoria cone, Mendoza, Argentina: Central European Journal of Geosciences, 3(2), 102-118.

Newhall, C.G., Self, S., 1982, The volcanic explosivity index (VEI) an estimate of explosive magnitude for historical volcanism: Journal of Geophysical Research: Oceans, 87(C2), 1231-1238.

Noriega E., Noriega, A., 1923, La desecación de la ciénega de Zacapu y las leyes agrarias. Caso especial, único en el país: México, Archivo General de la Nación, 58 pp.

Ordóñez, E., 1947, El volcán Paricutín: México: Ciudad de México, México, Editorial Fantasía, 181 pp.

Ort, M.H., Elson, M.D., Anderson, K.C., Duffield, W.A., Hooten, J.A., Champion, D.E., Waring, G., 2008, Effects of scoria-cone eruptions upon nearby human communities: Geological Society of America Bulletin, 120(3-4), 476-486.

Osorio-Ocampo, S., Macías, J.L., Pola, A., Cardona-Melchor, S., Sosa-Ceballos, G., Garduño-Monroy, V.H., Layer, P.W., García-Sánchez, L., Perton, M., Benowitz, J., 2018, The eruptive history of the Pátzcuaro Lake area in the Michoacán Guanajuato Volcanic Field, central México: Field mapping, C-14 and ${ }^{40} \mathrm{Ar} /{ }^{39} \mathrm{Ar}$ geochronology: Journal of Volcanology and Geothermal Research, 358, 307-328.

Pacheco, J.F., Valdés-González, C., Delgado, H., Singh, S.K., Zuñiga, F.R., Mortera-Gutiérrez, C.A., Santoyo, M.A., Domínguez, J., Barrón, R., 1999, Tectonic implications of the earthquake swarm of 1997 in the Michoacan Triangle, Mexico: Journal of South American Earth Sciences, 12(6), 567-577.

Pereira, G., Forest, M., Jadot, E., Darras, V., 2021, Ephemeral cities? The longevity of the Postclassic Tarascan urban sites of Zacapu Malpaís and its consequences on the migration process, in Arnauld, M.C., Beekman, C., Pereira, G., (eds.) Mobility and Migration in Ancient Mesoamerican Cities: Boulder, CO, USA, University Press of Colorado, 208-231.

Pioli, L., Erlund, E., Johnson, E., Cashman, K., Wallace, P., Rosi, M., Granados, H.D., 2008, Explosive dynamics of violent Strombolian eruptions: the eruption of Parícutin Volcano 1943-1952 (Mexico): Earth and Planetary Science Letters, 271(1-4), 359-368.

Pioli, L., Azzopardi, B.J., Cashman, K.V., 2009, Controls on the explosivity of scoria cone eruptions: Magma segregation at conduit junctions: Journal of Volcanology and Geothermal Research, 186(3-4), 407-415.

Porter, S. C., 1972, Distribution, morphology, and size frequency of cinder cones on Mauna Kea volcano, Hawaii: Geological Society of America Bulletin, 83(12), 3607-3612.

Ramírez-Uribe, I., Siebe, C., Salinas, S., Guilbaud, M.N., Layer, P., Benowitz, J., $2019,{ }^{14} \mathrm{C}$ and ${ }^{40} \mathrm{Ar} /{ }^{39} \mathrm{Ar}$ radiometric dating and geologic setting of young lavas of Rancho Seco and Mazcuta volcanoes hosting archaeological sites at the margins of the Pátzcuaro and Zacapu lake basins (central Michoacán, Mexico): Journal of Volcanology and Geothermal Research, 388, 106674, 1-22, https://doi.org/10.1016/j.jvolgeores.2019.106674

Ramírez-Uribe, I., Siebe, C., Chevrel, M.O., Fisher, C.T., 2021, Rancho Seco monogenetic volcano (Michoacán, Mexico): Petrogenesis and lava flow emplacement based on LiDAR images. Journal of Volcanology and Geothermal Research, Vol. 411, p. 1-19, https://doi.org/10.1016/j. jvolgeores.2020.107169 
Rasoazanamparany, C., Widom, E., Siebe, C., Guilbaud, M.N., Spicuzza, M.J., Valley, J.W., Valdés, G., Salinas, S., 2016, Temporal and compositional evolution of Jorullo volcano, Mexico: Implications for magmatic processes associated with a monogenetic eruption: Chemical Geology, 434, 62-80, https://doi.org/10.1016/j.chemgeo.2016.04.004

Reyes-Guzmán, N., 2017, Geología volcánica de la región occidental de la cuenca lacustre de Zacapu, Michoacán y su importancia para la arqueología: Mexico City, Mexico, Facultad de Ciencias, Universidad Nacional Autónoma de México, Bachelor Thesis, 113 pp.

Reyes-Guzmán, N., Siebe, C., Chevrel, M.O., Guilbaud, M.N., Salinas, S., Layer, P., 2018, Geology and radiometric dating of Quaternary monogenetic volcanism in the western Zacapu lacustrine basin (Michoacán, México): implications for archeology and future hazard evaluations: Bulletin of Volcanology, 80(2), 18, 1-20, https://doi.org/10.1007/s00445-018-1193-5

Reyes-Guzmán, N., Siebe, C., Chevrel, O.M., Pereira, G., 2021. Late Holocene Malpaís de Zacapu (Michoacán, Mexico) andesitic lava flows: Rheology and eruption properties based on LiDAR image: Bulletin of Volcanology, 83, 28, https://doi.org/10.1007/s00445-021-01449-0

Riggs, N.R., Duffield, W.A., 2008, Record of complex scoria cone eruptive activity at Red Mountain, Arizona, USA, and implications for monogenetic mafic volcanoes: Journal of Volcanology and Geothermal Research, 178(4), 763-776.

Romero, C., Galindo, I., Sánchez, N., Martín-González, E., Vegas, J., 2021, SynEruptive Lateral Collapse of Monogenetic Volcanoes: The Case of Mazo Volcano from the Timanfaya Eruption (Lanzarote, Canary Islands), in Updates in Volcanology - Transdisciplinary Nature of Volcano Science: Intech Open, http://dx.doi.org/10.5772/intechopen.93882 (Online first)

Rowe, M.C., Peate, D.W., Ukstins Peate, I., 2011, An investigation into the nature of the magmatic plumbing system at Paricutin Volcano, Mexico: Journal of Petrology, 52(11), 2187-2220.

Rowland, S.K., Jurado-Chichay, Z., Ernst, G., Walker, G.P.L., 2009, Pyroclastic deposits and lava flows from the 1759-1774 eruption of El Jorullo, México: aspects of 'violent Strombolian' activity: Studies in volcanology: the legacy of George Walker: Geological Society of London, Special Publications of IAVCEI, 2, 105-128.

Scott, D.H., Trask, N.J., 1971, Geology of the lunar crater volcanic field, Nye County, Nevada: United States Geological Survey (USGS), Professional Paper 599-I, 15 pp.

Segerstrom, K., 1950, Erosion studies at Paricutin, state of Michoacán, Mexico: U.S. Geological Survey Bulletin, 965-A, 1-164.

Settle, M.A., 1979, The structure and emplacement of cinder cone fields: American Journal of Science, 279(10), 1089-1107.

Siebe, C., Macías, J.L., 2006, Volcanic hazards in the Mexico City metropolitan area from eruptions at Popocatépetl, Nevado de Toluca, and Jocotitlán stratovolcanoes and monogenetic scoria cones in the Sierra Chichinautzin Volcanic Field: Special Papers-Geological Society of America, 402, 253-329.

SSN (Servicio Sismológico Nacional), 2020, Reporte especial Secuencia sísmica del 5 de enero al 10 de marzo de 2020 Michoacan (M 4.1): Ciudad de México, Mexico, Instituto de Geofísica, Universidad Nacional Autónoma de México, URL: http://www.ssn.unam.mx, query date: january 2021.

Siebe, C., Guilbaud, M.N., Salinas, S., Kshirsagar, P., Chevrel, M.O., De la Fuente, J.R., Hernández-Jiménez, A., Godínez, L., 2014, Monogenetic volcanism of the Michoacán-Guanajuato volcanic field: Maar craters of the Zacapu basin and domes, shields, and scoria cones of the Tarascan highland (Paracho-Paricutin región, in Field guide, Pre-meeting Fieldtrip for the $5^{\text {th }}$ International Maar Conference (5IMC-IAVCEI): Querétaro, Mexico, 33 pp.

Suter, M., Quintero, O., Johnson, C.A., 1992, Active faults and state of stress in the central part of the Trans-Mexican Volcanic Belt, Mexico 1. The Venta de Bravo Fault: Journal of Geophysical Research Solid Earth, 97(B8), 11983-11993.

Suter, M., López-Martínez, M., Quintero-Legorreta, O., Carrillo-Martínez, M., 2001, Quaternary intra-arc extension in the central Trans-Mexican volcanic belt: Bulletin of the Geological Society of America, 113(6), 693-703, https://doi.org/10.1130/0016-7606(2001)113<0693:QIAEIT> 2.0.CO; 2

Taddeucci, J., Pompilio, M., Scarlato, P., 2004, Conduit processes during the July-August 2001 explosive activity of Mt. Etna (Italy): inferences from glass chemistry and crystal size distribution of ash particles: Journal of Volcanology and Geothermal Research, 137(1-3), 33-54.

Takada, A., 1994, The influence of regional stress and magmatic input on styles of monogenetic and polygenetic volcanism: Journal of Geophysical Research Solid Earth, 99(B7), 13563-13573.

Tibaldi, A., 1995, Morphology of pyroclastic cones and tectonics: Journal of Geophysical Research Solid Earth, 100(B12), 24521-24535.

Valentine, G.A., Gregg, T.K.P., 2008, Continental basaltic volcanoes-processes and problems: Journal of Volcanology and Geothermal Research, 177(4), 857-873.

Valentine, G.A., Keating, G.N., 2007, Eruptive styles and inferences about plumbing systems at Hidden Cone and Little Black Peak scoria cone volcanoes (Nevada, USA): Bulletin of Volcanology, 70(1), 105-113.

Valentine, G. A., Perry, F. V., Krier, D., Keating, G. N., Kelley, R. E., Cogbill, A. H., 2006, Small-volume basaltic volcanoes: Eruptive products and processes, and posteruptive geomorphic evolution in Crater Flat (Pleistocene), southern Nevada: Geological Society of America Bulletin, 118(11-12), 1313-1330.

Valentine, G.A., Krier, D.J., Perry, F.V., Heiken, G., 2007, Eruptive and geomorphic processes at the Lathrop Wells scoria cone volcano: Journal of Volcanology and Geothermal Research, 161(1-2), 57-80.

Younger, Z.P., Valentine, G.A., Gregg, T.K.P, 2019, 'A'ā lava emplacement and the significance of rafted pyroclastic material: Marcath volcano (Nevada, USA): Bulletin of Volcanology, 81, 50, https://doi-org.pbidi.unam. $m x: 2443 / 10.1007 / s 00445-019-1309-6$.

Manuscript received: march 4, 2021

Corrected manuscript received: june 10, 2021

Manuscript accepted: june 14, 2021 